Marquette University

e-Publications@Marquette

\title{
A-C Estrogens as Potent and Selective Estrogen Receptor-Beta Agonists (SERBAs) to Enhance Memory Consolidation under Low- Estrogen Conditions
}

\author{
Alicia M. Hanson \\ Concordia University - Wisconsin \\ K. L. Iresha Sampathi Perera \\ Marquette University \\ Jaekyoon Kim \\ University of Wisconsin - Milwaukee \\ Rajesh K. Pandey \\ Marquette University \\ Noreena Sweeney \\ Concordia University of Wisconsin
}

See next page for additional authors

Follow this and additional works at: https://epublications.marquette.edu/chem_fac

Part of the Chemistry Commons

\section{Recommended Citation}

Hanson, Alicia M.; Perera, K. L. Iresha Sampathi; Kim, Jaekyoon; Pandey, Rajesh K.; Sweeney, Noreena; Lu, Xingyun; Imhoff, Andrea; Mackinnon, Alexander Craig; Wargolet, Adam J.; Van Hart, Rochelle M.; Frick, Karyn M.; Donaldson, William A.; and Sem, Daniel S., "A-C Estrogens as Potent and Selective Estrogen Receptor-Beta Agonists (SERBAs) to Enhance Memory Consolidation under Low-Estrogen Conditions" (2018). Chemistry Faculty Research and Publications. 962.

https://epublications.marquette.edu/chem_fac/962 


\section{Authors}

Alicia M. Hanson, K. L. Iresha Sampathi Perera, Jaekyoon Kim, Rajesh K. Pandey, Noreena Sweeney, Xingyun Lu, Andrea Imhoff, Alexander Craig Mackinnon, Adam J. Wargolet, Rochelle M. Van Hart, Karyn M. Frick, William A. Donaldson, and Daniel S. Sem 
Marquette University

\section{e-Publications@Marquette}

\section{Chemistry Faculty Research and Publications/College of Arts and Sciences}

This paper is NOT THE PUBLISHED VERSION; but the author's final, peer-reviewed manuscript. The published version may be accessed by following the link in the citation below.

Journal of Medicinal Chemistry, Vol. 61, No. 11 (May 9, 2018): 4720-4738. DOI. This article is (C) American Chemical Society and permission has been granted for this version to appear in ePublications@Marquette. American Chemical Society does not grant permission for this article to be further copied/distributed or hosted elsewhere without the express permission from American Chemical Society.

\section{A-C Estrogens as Potent and Selective Estrogen Receptor-Beta Agonists (SERBAs) to Enhance Memory Consolidation under Low- Estrogen Conditions}

Alicia M. Hanson ${ }^{\dagger}$, K. L. Iresha Sampathi Perera ${ }^{\ddagger}$, Jaekyoon Kim ${ }^{\S}$, Rajesh K. Pandey $^{\ddagger}$, Noreena Sweeney ${ }^{\dagger}$, Xingyun $\mathrm{Lu}^{\dagger}$, Andrea Imhoff ${ }^{\dagger}$, Alexander Craig Mackinnon", Adam J. Wargolet ${ }^{\perp}$, Rochelle M. Van Hart ${ }^{\perp}$, Karyn M. Frick*§, William A. Donaldson* ${ }^{\ddagger}$, and Daniel S. Sem ${ }^{*}$

${ }^{\dagger}$ Department of Pharmaceutical Sciences, Center for Structure-Based Drug Design and Development, Concordia University Wisconsin, Mequon, Wisconsin 53097, United States

‡ Department of Chemistry, Marquette University, P.O. Box 1881, Milwaukee, Wisconsin 532011881, United States

$\S$ Department of Psychology, University of Wisconsin-Milwaukee, 2441 East Hartford Avenue, Milwaukee, Wisconsin53211, United States

" Department of Pathology, Medical College of Wisconsin, 9200 West Wisconsin Avenue, Milwaukee, Wisconsin 53226, United States 
${ }^{\perp}$ Department of Natural Science, Concordia University Wisconsin, Mequon, Wisconsin 53097, United States

*For D.S.M.: E-mail: daniel.sem@cuw.edu. Phone: 262-243-2778., *For W.A.D.: Email: william.donaldson@marquette.edu., *For K.M.F.: E-mail: frickk@uwm.edu.

Abstract

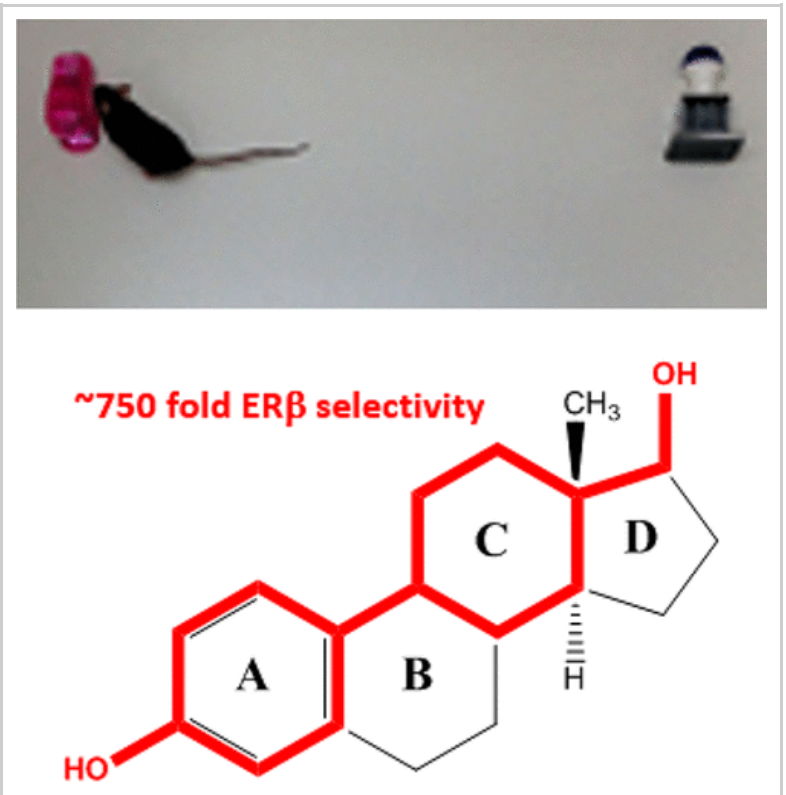

Estrogen receptor-beta $(E R \beta)$ is a drug target for memory consolidation in postmenopausal women. Herein is reported a series of potent and selective ER $\beta$ agonists (SERBAs) with in vivo efficacy that are A-C estrogens, lacking the B and D estrogen rings. The most potent and selective A-C estrogen is selective for activating ER relative to seven other nuclear hormone receptors, with a surprising 750-fold selectivity for the $\beta$ over $\alpha$ isoform and with EC 50 of $20-30 \mathrm{nM}$ in cell-based and direct binding assays. Comparison of potency in different assays suggests that the ER isoform selectivity is related to the compound's ability to drive the productive conformational change needed to activate transcription. The compound also shows in vivo efficacy after microinfusion into the dorsal hippocampus and after intraperitoneal injection (0.5 $\mathrm{mg} / \mathrm{kg}$ ) or oral gavage $(0.5 \mathrm{mg} / \mathrm{kg})$. This simple yet novel A-C estrogen is selective, brain penetrant, and facilitates memory consolidation.

\section{Introduction}

ER $\beta$ agonists have a number of promising clinical applications.(1) Current ER $\beta$ agonist drug lead molecules possess a phenolic ring, with varying substituted aromatic ring systems on the other half of the molecule, typically comprising another phenolic or indole-like ring system (Figure 1a). One of these, WAY-200070 (benzoxazole), has shown efficacy as an anxiolytic/antidepressant and has 68-fold selectivity for ER $\beta$ over ER $\alpha .(1-3)$ Some ERß agonists have progressed into human clinical trials for different disease indications, ranging from schizophrenia (Eli Lilly; NCT01874756) to fragile-X syndrome (Parc de Salut Mar; NCT01855971) to memory loss and hot flashes (National Institutes on Aging; NCT01723917).(4) Studies presented herein focus on one of the more promising new clinical applications of ER $\beta$ agonists for treating neuronal symptoms caused by estrogen deficiency in menopause, as illustrated in animal model studies using diarylpropionitrile (DPN).(5)

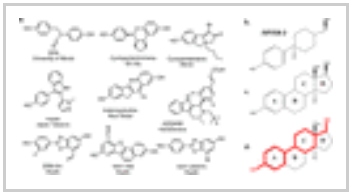


Figure 1. Estrogen receptor agonist structures. (a) Previously reported ER $\beta$ agonists. Figure adapted from ref (35). (b) Structure of ISP358-2, (c) estradiol ( $\left.E_{2}\right)$, and (d) ISP358-2 (red) overlaid on top of $E_{2}$ to illustrate the similarity to the naturally occurring estrogen.

$17 \beta$-Estradiol $\left(E_{2}\right)$ is a critical modulator of hippocampal synaptic plasticity and hippocampal-dependent memory formation in male and female rodents.(6) $E_{2}$ levels decrease in both sexes as people age but drop much more precipitously in women during the menopausal transition. ER $\beta$ is the predominant ER isoform in the hippocampus and plays an important role in mediating estradiol's effects on neural plasticity and neuroprotection, which could be pivotal during aging and in Alzheimer's disease (AD). For example, overexpression of ERB in a rat model of AD significantly reduced hippocampal AD pathology and improved learning and memory.(7) Moreover, specific alleles of the gene for ER $\beta$ (Esr2), but not ER $\alpha$, are associated with decreased $A D$ risk in men and women,(8) supporting $E R \beta$ as a putative drug target for $A D$.

APOE4 is the most well established genetic risk factor for Alzheimer's disease (AD). Women with the APOE4 genotype are 2-4 times more likely to develop AD than women without APOE4 or than men of any other $A P O E$ genotype.(9-11) APOE4 carriers are also much more likely to show symptoms of anxiety and depression.(12) A major contributor to these risks in women is menopausal estrogen loss, as estrogens are neuroprotective for brain regions like the hippocampus and cortex that mediate cognitive function and deteriorate in AD.(13) As such, drugs that facilitate estrogen-mediated effects on cognition, like the selective ER $\beta$ agonists (SERBAs) being developed herein, may reverse memory loss and alleviate anxiety and depression in aging females, but estrogen-based hormone replacement therapy is associated with increased risk of various diseases (thought to be associated with ER $\alpha$ agonist activity), including breast cancer (especially lobular) as well as stroke, gallbladder disease, and venous thromboembolism.(14-18)Accordingly, any ER $\beta$ agonist therapeutic should be selective for ER $\beta$ over ER $\alpha$ agonist activity.

Recently, we reported a novel ER $\beta$ agonist that was more selective for ER $\beta$ versus ER $\alpha$ activation than previously reported clinical candidates.(19) This ER $\beta$ agonist was in a unique structural class, comprising a phenol ring tethered to a 4-hydroxymethyl-cycloheptane ring system. However, the presence of the 4-substituted cycloheptane ring presents synthetic and stereochemistry challenges, making it less desirable as a drug lead. Herein is reported the optimization and characterization of a related class of molecules, comprised of a 4hydroxymethyl-cyclohexane ring tethered to a phenol ring, making it an A-C estrogen that closely resembles the naturally occurring estrogen molecule but lacks the $B$ and $D$ rings (Figure $1 b-d)$. Whereas $A-C D$ estrogens have been widely studied and reported to have up to 15 -fold selectivity for $E R \beta,(16-23)$ the simpler $A-C$ estrogens reported herein show even higher selectivity for ER $\beta$ over $E R \alpha$. These A-C estrogens represent a surprisingly simple yet novel class of isoform selective ER $\beta$ agonists, with potential for treating age-related memory decline in postmenopausal women.

\section{Results}

\section{Compound Synthesis}

Commercially available 4-(4-hydroxyphenyl)cyclohexanone 1 was transformed into $2^{\circ}$ or $3^{\circ}$ alcohols 2 or $\mathbf{3}$ by reaction with $\mathrm{NaBH}_{4}$ or excess methyl lithium, respectively, or into oxime $\mathbf{4}$ by condensation with hydroxylamine (Scheme 1). The stereochemistries of $\mathbf{2}$ and $\mathbf{3}$ were assigned based on their NMR spectral data. In particular, for $2^{\circ}$ alcohol 2, the alcohol methane proton appears as a triplet of triplets at $\delta 2.38(\mathrm{~J}=11.8,3.4 \mathrm{~Hz})$; the large couplings are consistent with an axial-axial disposition of this proton, and thus the hydroxyl group is equatorial. Signals at $\delta 69.5$ and $31.1 \mathrm{ppm}$ in the ${ }^{13} \mathrm{C}$ NMR spectrum of 3, assigned to the $3^{\circ}$ alcohol and methyl carbons, are in good agreement with cis-1,4-alcohols of this type.(24) The $t$-butyldimethylsilyl ether 5underwent olefination with the ylide generated from methyltriphenylphosphonium bromide to give 6 . Cleavage of the silyl ether using TBAF gave 7; catalytic hydrogenation of $\mathbf{7}$ gave $\mathbf{8}$ as a mixture of stereoisomers. Reaction of $\mathbf{7}$ with excess paraformaldehyde, $\mathrm{MgCl}_{2}$, and $\mathrm{NEt}_{3}$ gave the substituted salicaldehyde $\mathbf{9}$, which upon reaction with hydroxylamine afforded the oxime 10. Dihydroxylation of 6, followed by cleavage of the silyl ether, gave $\mathbf{1 2}$ as a single stereoisomer after chromatographic purification. The stereochemistry of $\mathbf{1 2}$ was assigned as indicated 
based on the known stereochemistry of osmium-catalyzed dihydroxylation of 4-t-

butylmethylenecyclohexane.(25) Hydroboration-oxidation of 6 using $\mathrm{BH}_{3}-\mathrm{THF}$ produced an inseparable mixture of stereoisomeric primary alcohols cis-13 and trans-14 in a 2:1 ratio as determined by integration of the ${ }^{1} \mathrm{H}$ NMR signals for the hydroxymethylene protons for each $(\delta 3.60$ and $3.39 \mathrm{ppm}$, respectively). The stereochemistry of the isomers was tentatively assigned on the basis of the relative chemical shift of these two signals; the signal for an axial hydroxymethylene (i.e., cis-isomer) appears downfield compared to that for an equatorial hydroxymethylene.(24) Alternatively, hydroboration-oxidation using 9-BBN afforded a mixture in which trans14 was in greater proportion compared to cis-13 (2:3, cis:trans). The use of these two borane reagents to tune the cis:trans outcome for 4-substituted methylenecyclohexanes has previously been reported.(26,27)Cleavage of the silyl ether using TBAF gave a mixture of stereoisomeric 4-(4-hydroxymethylcyclohexyl)phenols cis15/trans-16. Treatment of a mixture of the stereoisomers 15/16 (2:3, cis:trans) with DDQ (0.5 equiv) led to a separable mixture of a bicyclic ether 17 and trans-16. The tentative structural assignment for trans-16 was corroborated by single-crystal X-ray diffraction analysis (Figure 7a).(28) Isolation of the unreacted trans-16 is rationalized on the basis of the faster rate of oxidation of cis-15. Because oxidation of either cis- or trans-4-(4hydroxymethylcyclohexyl)phenol proceeds via the same benzylic carbocation intermediate (i.e., 18, Scheme 2), the activation energy for the formation of this intermediate will be lower for the less stable cis-15 in comparison to trans-16, and thus oxidative cyclization of the cis-isomer will be faster. Reaction of $\mathbf{1 7}$ with $\mathrm{MgCl}_{2}$ and trimethylamine led to an intramolecular elimination reaction to afford the cyclohexene ( \pm )-19 (Scheme 1 ). The structure of 19 was assigned on the basis of its NMR spectral data; in particular, the signal for the olefinic proton appears as a narrow multiplet at ca. $\delta 5.95$ ppm. This signal is characteristic of other 1-(4hydroxyphenyl)cyclohexenes.(29)

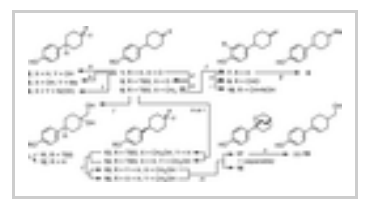

Scheme 1. ${ }^{\text {a }}$ Reagents: (a) $\mathrm{NaBH}_{4} / \mathrm{MeOH}$ (90\%); (b) MeLi/Et $2 \mathrm{O}$ (37\%); (c) $\mathrm{H}_{2} \mathrm{NOH}-\mathrm{HCl}$, Amberlyst, ethanol (70\%); (d) TBSCl, imidazole (83\%); (e) $\mathrm{Ph}_{3} \mathrm{PCH}_{3}{ }^{+} \mathrm{Br}^{-}, n$-BuLi (84\%); (f) TBAF/THF (73-78\%); (g) $\mathrm{H}_{2}, \mathrm{Pd} / \mathrm{C}$, (h) paraformaldehyde, $\mathrm{MgCl}_{2}$, $\mathrm{NEt}_{3}$ (40\%); (i) $\mathrm{H}_{2} \mathrm{NOH}-\mathrm{HCl}, \mathrm{NaHCO}_{3}$, ethanol (69\%); (j) cat. OsO 4 , $\mathrm{NMO}$ (1.4 equiv) (86\%); (k) $\mathrm{BH}_{3}-\mathrm{THF}$, then $30 \% \mathrm{H}_{2} \mathrm{O}_{2} / 1 \mathrm{~N}$ $\mathrm{NaOH}$; (l) 9-BBN, then $30 \% \mathrm{H}_{2} \mathrm{O}_{2} / 1 \mathrm{~N} \mathrm{NaOH}$; (m) DDQ (0.5 equiv)/ $\mathrm{CH}_{2} \mathrm{Cl}_{2}$ (16, 47\%; 17, 37\%); (n) $\mathrm{MgCl}_{2}, \mathrm{NEt}_{3}(78 \%)$.

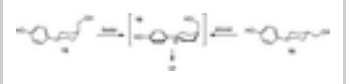

Scheme 2. Oxidation of the cis- or trans-4-(4-Hydroxymethylcyclohexyl)phenol via the Same Benzylic Carbocation Intermediate

Silyl ether 20 (prepared from 1) underwent Horner-Emmons olefination with triethyl phosphonoacetate to afford the unsaturated ester ( \pm )-21; desilylation with TBAF gave the phenol ( \pm )-22 (Scheme 3). Reduction of 21 with DIBAL, followed by deprotection of the silyl ether, yielded the allylic alcohol ( \pm )-24. Catalytic hydrogenation of 24 gave a separable mixture of alcohol $\mathbf{2 5}$ and the over-reduced ethyl cyclohexane derivative $\mathbf{2 6}$.

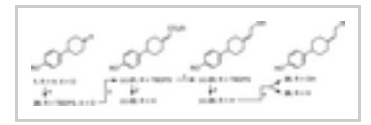

Scheme 3. aa Reagents: (a) TBDPSCl, imidazole (93\%); (b) $\mathrm{EtO}_{2} \mathrm{CCH}_{2} \mathrm{P}(\mathrm{O})(\mathrm{OEt})_{2}, \mathrm{NaH}$ (95\%); (c) DIBAL, $\mathrm{CH}_{2} \mathrm{Cl}_{2},-40{ }^{\circ} \mathrm{C}$ (quant); (d) TBAF (80\%); (e) $\mathrm{H}_{2}$ (30 psi), 20\% Pd/C (25, 14\%; 26, 60\%).

\section{TR-FRET and Cell-Based Transcriptional Assays}

Initial screening of compounds was performed in a TR-FRET displacement assay, which detects binding to the ER $\beta$ LBD (see Figure 2 for dose-response curves for selected compounds and Supporting Information, Figure S1, for doseresponse curves for all compounds). In this assay, $\mathrm{EC}_{50} \mathrm{~S}$ were measured for all compounds that were synthesized, with 
$\mathrm{EC}_{50}$ values summarized in Table 1. The most potent compounds were $\mathbf{1 6}$ (hereafter referred to as ISP358-2)

(hydroxymethyl substitution), 25 (hydroxyethyl substitution), and 8 (methyl substitution), which all had $\mathrm{EC}_{50} \mathrm{~S}<30 \mathrm{nM}$ for ERB. ISP358-2 is the pure trans isomer and was found to bind with higher affinity to ER $\beta$ than the mixture of cisand trans-stereoisomers (15/16). While having a methylene (ISP358-2) or ethylene (25) linker to the hydroxyl group leads to potency, the direct substitution of the hydroxyl on the cyclohexane ring yields a significant decrease in affinity ( $\mathrm{EC}_{50}$ of 7,520 $\mathrm{nM}$ for 2). While introduction of unsaturation into the alkyl linker (24) also led to a decrease in affinity $(680 \mathrm{nM})$, introduction of unsaturation into the cyclohexane ring (18) only decreased affinity modestly (49 $n M$ ). ISP358-2 was also tested for binding to $E R \alpha$ and bound with only 12 -fold higher affinity to $E R \beta$ (EC ${ }_{50}$ of 24 $\mathrm{nM}$; Figure $2 \mathrm{~b}$ ) in this TR-FRET assay, which measures direct binding to the isolated LBD.

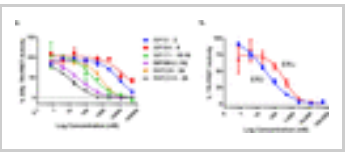

Figure 2. Estrogen receptor binding assays. (a) TR-FRET binding assay for binding to the ligand binding domain (LBD) of ERB. (b) ISP358-2 binding to the LBDs of ER $\beta$ and ER $\alpha$. ISP358-2 has modest 12 -fold selectivity for $E R \beta(E C 50=24 \pm 5 \mathrm{nM}$ ) relative to $E R \alpha\left(E C_{50}=289 \pm 92 \mathrm{nM}\right)$ in this assay.

Table 1. Estrogen Receptor Assay Dataa

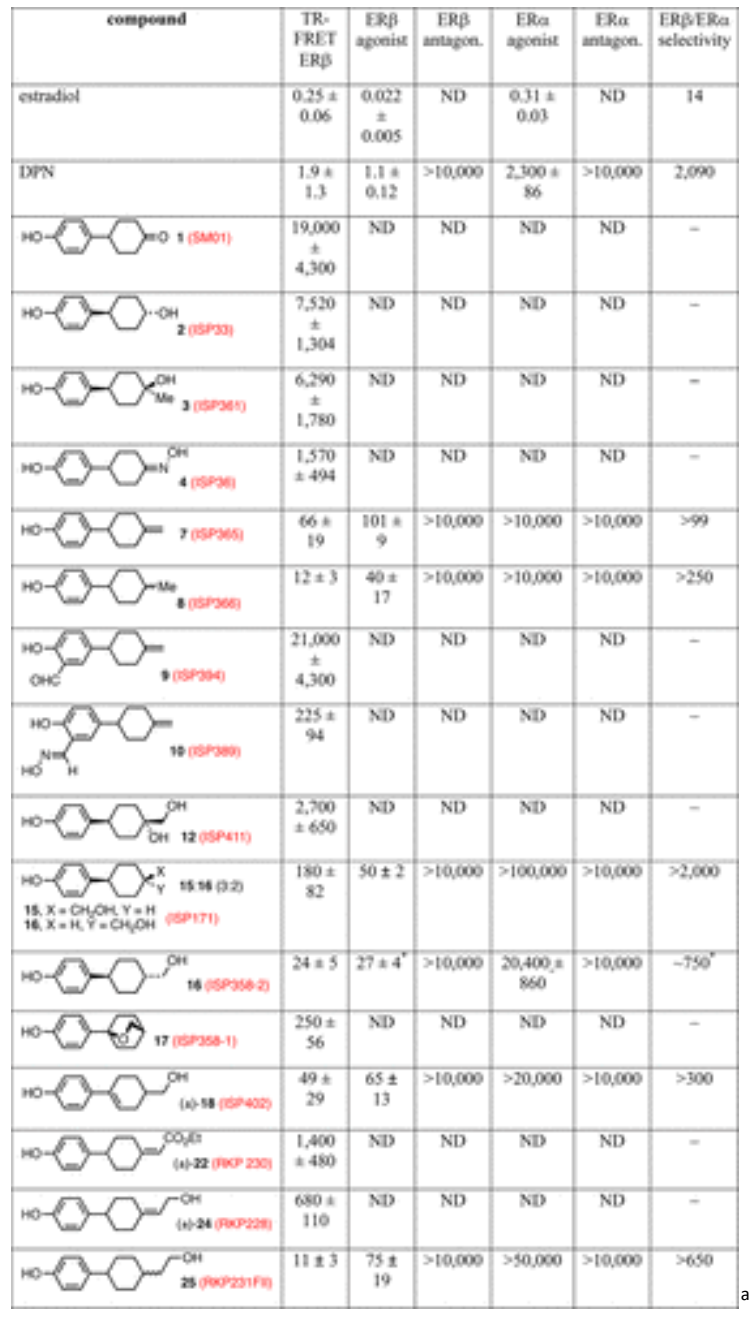

Reported values are $\mathrm{EC}_{50}$, with values in $\mathrm{nM}$. *Average of two data sets with $\mathrm{EC}_{50}$ s of $31 \pm 7 \mathrm{nM}$ (Figure $5 \mathrm{a}$ ) and $23 \pm 8 \mathrm{nM}$ (Supporting Information, Figure S2), so selectivity ranges from 658 to 886 with an average of 750.

ISP358-2 was further screened in a nuclear hormone receptor functional assay (Figure 3), where transcriptional activation was measured due to binding and activation of a chimeric receptor comprised of the LBD of a hormone 
receptor of interest (e.g., ERB) tethered to the DNA binding domain (DBD) of GAL4. This assay was done to assess selectivity for activating estrogen receptor versus other nuclear hormone receptors. No significant agonist activity was observed for compound ISP358-2 for any of the nuclear hormone receptors tested (except for the estrogen receptor) at concentrations ranging from 0.25 to $25 \mu \mathrm{M}$ (Figure 3a). Thus, ISP358-2 is not an agonist for the following receptors: androgen receptor (AR), glucocorticoid receptor (GR), mineralocorticoid receptor (MR), peroxisome proliferator-activated receptor (PPARS), progesterone receptor (PR), thyroid hormone receptor (TRß), and vitamin D receptor (VDR) (see Supporting Information, Table S1, for control compound $\mathrm{EC}_{50} \mathrm{~S}$ for each nuclear hormone tested). In a follow-up 10-point titration in this same assay, ISP358-2 was found to be 2.6-fold selective for binding and activating the full-length chimeric $E R \beta(357 \pm 26 \mathrm{nM}$ ) relative to full-length chimeric ER $\alpha(930 \pm 69 \mathrm{nM})$. This assay (Figure 3) measures activation of transcription rather than simply binding of agonist to the ER LBD (as in Figure 2), but it uses an unnatural chimeric protein (ER LBD fused to a GAL4 DBD) that may not accurately reflect the actual agonistinduced activation that occurs under native conditions.

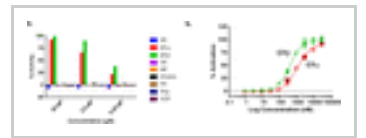

Figure 3. Nuclear hormone receptor specificity assay for ISP358-2. (a) Agonist activity was measured in the GeneBLAzer cellbased transcriptional activation assay at three concentrations of ISP358-2, using chimeric nuclear hormone receptors (NRs) comprised of the relevant NR ligand binding domains (LBDs) and the DNA binding domain (DBD) from GAL4. Assay was with nine different NRs: androgen receptor (AR), glucocorticoid receptor (GR), mineralocorticoid receptor (MR), peroxisome proliferator-activated receptor (PPARS), progesterone receptor (PR), thyroid hormone receptor (TR $\beta$ ), and vitamin $D$ receptor (VDR). ISP358-2 has high selectivity for binding to ER relative to other nuclear receptors (NRs). (b) Agonist activity dose-response curve (open symbols) in the GeneBLAzer assay for ER $\beta$ and $E R \alpha$, showing a modest 2.6-fold selectivity for $\operatorname{ER} \beta\left(E_{50}=357 \pm 26 \mathrm{nM}\right)$ over $E R \alpha\left(E C_{50}=930 \pm 69 \mathrm{nM}\right)$. Data from (a) are included for comparison (closed symbols).

When the coactivator form of the TR-FRET LBD binding assay was performed (Figure 4a), the ISP358-2 compound (Figure $4 \mathrm{~b}$ ) was found to be 15 -fold selective (Figure 4c) for binding to ER and recruiting the PPAR $\gamma$ coactivator peptide to $E R \beta(191 \pm 15 \mathrm{nM})$ relative to $E R \alpha(2,940 \pm 390 \mathrm{nM})$. This assay measures activation of the ER LBD, in that it measures binding and agonist-induced recruitment of the coactivator peptide rather than simply binding of agonist to the receptor.

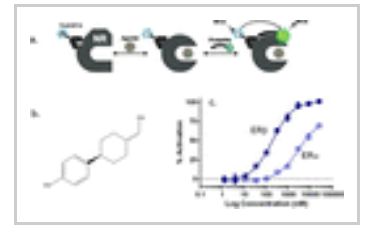

Figure 4. Specificity assay for ISP358-2 binding in a coactivator assay. (a) This assay measures recruitment of a labeled coactivator peptide to the ER $\alpha$ or ER $\beta$ LBD, induced by the binding of an ER agonist (ISP358-2, in this case). The coactivator peptide is derived from the PPARY coactivator protein 1a. Figure is adapted from the ThermoFisher manual. (b) Chemical structure of ISP358-2. (c) ISP358-2 dose-response curve in the coactivator assay, giving an IC 50 of $191 \pm 15 \mathrm{nM}$ for ER $\beta$ and $2,940 \pm 390 \mathrm{nM}$ for $E R \alpha$, giving an $E R \beta$ selectivity of 15 -fold.

Finally, a cell-based transcriptional activation assay, which employs a full length and native ER (comprised of an ER LBD and an ER DBD), was performed. Unlike the previous assays, this assay is cell-based, so it best mimics the in vivo situation. The most potent and selective compound tested in this assay is ISP358-2, which has an ER $\beta$ agonist potency of $31 \pm 7 \mathrm{nM}$ (Figure 5a and Supporting Information, Figure S2a; the assay was performed in duplicate, with values of $31 \mathrm{nM}$ and $23 \mathrm{nM}$ obtained, for an average of $27 \mathrm{nM}$ ) and an ER $\alpha$ agonist potency of 20,400 $\pm 859 \mathrm{nM}$ (Figure 5b). This makes the ER $\beta / E R \alpha$ selectivity ratio $~ 750$ in this more physiologically relevant assay. ISP358-2 showed no antagonist activity for ER $\beta$ (Figure 5c) or ER $\alpha$ (Figure $5 \mathrm{~d}$ ) at concentrations up to $10 \mu \mathrm{M}$. 


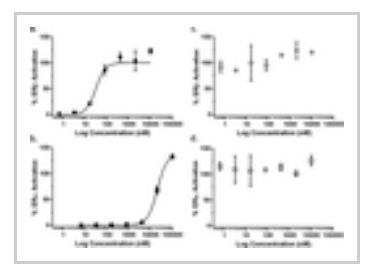

Figure 5. Specificity assay for ISP358-2 in cell-based assays. (a) ER $\beta$ and (b) ER $\alpha$ agonist activity, based on activation of transcription by a full length estrogen receptor. (c) ER $\beta$ and (d) ER $\alpha$ antagonist activity, based on inhibition of estradiolinduced transcription by an antagonist compound. Average ERß agonist potency is $27 \pm 4 \mathrm{nM}$ (data here has EC 50 of $31 \pm 7$ ) in (a), and ER $\alpha$ agonist potency is 20,400 $\pm 860 \mathrm{nM}$. This gives an ERß selectivity of $\sim 750$-fold. No measurable antagonist activity was observed for ER $\beta$ or ER $\alpha$ at concentrations of ISP358-2 up to $10 \mu \mathrm{M}$ in (c) and (d).

\section{In Vitro Druggability: CYP450 Binding, hERG and Nephelometry}

ISP358-2 shows no inhibition of CYP1A2 and CYP2D6, and only weak inhibition of CYP2C9 (EC $50=34 \pm 4.7 \mu \mathrm{M})$ and CYP3A4 (EC E $\left._{50} 89 \pm 18 \mu \mathrm{M}\right)$ (Figure 6). ISP358-2 does not bind to hERG, showing only $14 \%$ activity at $100 \mu \mathrm{M}$, and nephelometry (done for ISP171, 15/16, the mixture of isomers) shows no significant aggregation, indicating good solubility at concentrations up to $300 \mu \mathrm{M}$ (Supporting Information, Figure S3).

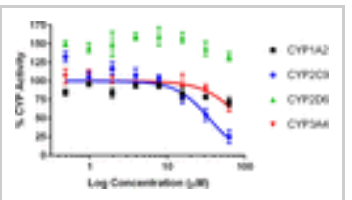

Figure 6. Cytochrome P450 inhibition by ISP358-2. Inhibition of CYP450 activity (Promega P450-Glo assay) by ISP358-2 for: CYP2D6 and CYP3A4 (EC50 $=89 \pm 18 \mu \mathrm{M})$, CYP1A2, and CYP2C9 $\left(\mathrm{EC}_{50}=34 \pm 4.7 \mu \mathrm{M}\right)$.

\section{Docking Studies}

ISP358-2 (Figure 7a) was docked into the binding site of agonist-conformation ER $\alpha$ in two conformations with similar docking energy. In one binding mode (Figure 6d,e), the phenolic hydroxyl interacts with the Arg394/Glu353 (energy = $-7.6 \mathrm{kcal} / \mathrm{mol}$ ), and in another mode the ISP358-2 molecule is flipped $180^{\circ}$ (energy $=-7.8 \mathrm{kcal} / \mathrm{mol}$ ) with the aliphatic hydroxyl interacting with Arg394/Glu353. ISP358-2 binds in the agonist-conformation ERß pocket (Figure 7f,g) with the phenolic hydroxyl interacting with the Arg394/Glu353 in the lowest energy docking pose (energy = $-8.0 \mathrm{kcal} / \mathrm{mol}$ ). In both cases, there are significant hydrophobic interactions between binding site residues and the bound ISP358-2, although the ER $\beta$ pocket is smaller and makes for a tighter fit. In both cases, the hydroxymethyl group is proximal enough (3.0 $\AA$ ) to the His524 to participate in the hydrogen bonding interaction that is typically seen for ER agonists, although in ER $\beta$ the hydrogen bond to the aliphatic alcohol may be with the backbone carbonyl of Gly472. In ER $\beta$, there are more hydrophobic interactions that constrain the hydroxymethyl-cyclohexyl ring (ring $\mathrm{C}$ ) to be nearly planar with the phenolic ring (ring A) (Figure 7c), as it is in the native estrogen molecule. This is in contrast to the binding pose in $E R \alpha$, where the two rings are nearly orthogonal (Figure $7 b$ ). The ER $\beta$ hydrophobic interactions are with Phe356, Met340, Phe355, and Leu298, near the phenol ring, and with Leu476 and Ile373 near the hydroxymethyl group and with Ala302 and Leu298 near the cyclohexane ring (Figure 7f,g). A control docking study of $E_{2}$ reproduced the expected binding orientation based on the crystal structure (Supporting Information, Figure S4).

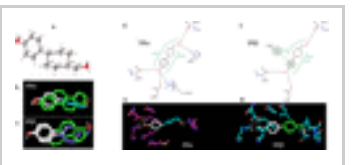

Figure 7. Structural analysis of ISP358-2. (a) Crystal structure (Ortep rendering) of ISP358-2, showing the trans stereochemistry of the cyclohexane ring. (b,d,e) Docked structure of ISP358-2 in the ER $\alpha$ binding pocket, showing: (b) binding orientation relative to estradiol (green) and $(d, e)$ interactions with active site residues, including hydrogen bonding with Arg394, Glu353, and His524. (c,f,g) Same as (b), (d), and (e) but for ISP358-2 bound to ERß. Hydrophobic interactions in ER $\beta$ are observed between the phenol ring of ISP358-2 and Phe356, Phe355, and Met340 and between the cyclohexane ring and Leu476, Ala302, Ile373, and Leu298. The phenol rings are colored white, and the hydroxymethylcyclohexane ring is cyan (in ER $\alpha,(\mathrm{e})$ ) or green (in ER $\beta,(\mathrm{g})$ ). Docking energy is $-7.6 \mathrm{kcal} / \mathrm{mol}$ in $\mathrm{ER} \alpha$ and $-8.0 \mathrm{kcal} / \mathrm{mol}$ in $\mathrm{ER} \beta$. 
2D ligand plots (d,f) were created using PoseView.(37) The ER $\alpha$ receptor for agonist (pdb 1ere)(36) and antagonist ( $p d b$ 1err)(48) conformations and the ER $\beta$ receptor for agonist ( $p d b 2 j \mathrm{j} 3)(49)$ and antagonist ( $p d b ~ 1 / 2 j)(50)$ conformations were used for docking calculations.

\section{Assessment of Memory Consolidation}

As described in detail in the Experimental Section, memory consolidation was assessed in all studies using acute treatments administered immediately after training. That is, for each task, mice completed a single training trial and then were immediately treated with control vehicle or experimental compounds. Memory consolidation was measured 24 or $48 \mathrm{~h}$ later. Briefly, in the object recognition task, mice explored two identical objects during training, immediately after which they were treated with the compounds described below. Memory for the training objects was tested $48 \mathrm{~h}$ later by allowing mice to explore one training object and one novel object. In the object placement task, mice again explored two identical objects and received immediate post-training treatments. Memory was tested $24 \mathrm{~h}$ later by allowing mice to explore a training object in its original location and a training object in a new location. More time than chance, or than the control group, spent with the novel or moved object indicated intact consolidation of memory for the training objects. Each mouse completed both tasks, the order of which was counterbalanced within each group. Two weeks separated bouts of testing to allow any acute effects of the drugs to dissipate before the next treatment.

\section{Dorsal Hippocampal Infusion}

We first investigated the effects of direct intrahippocampal infusion of ISP358-2 on object recognition and spatial memory consolidation in ovariectomized mice (Figure 8a). Five groups of mice were tested (Figure $8 \mathrm{~b}, \mathrm{c})$ : vehicle (negative control), DPN (positive control), and three doses of ISP358-2 (10 pg/hemisphere, $100 \mathrm{pg} /$ hemisphere, and 1 $\mathrm{ng} /$ hemisphere). For object placement (Figure 8b), one-sample $t$-tests indicated that mice receiving vehicle or $10 \mathrm{pg}$ of ISP358-2 did not spend significantly more time than chance with the moved object $\left(\operatorname{ts}_{(7)}=0.44\right.$ and 1.19 , respectively, $p>0.05 ; n=8$ ), indicating that these groups did not exhibit a memory for the training object location. In contrast, mice receiving DPN, 100 pg of ISP358-2, or 1 ng of ISP358-2 spent significantly more time than chance with the moved object $\left(t s_{(6)}=4.5,10.3\right.$, and 3.4 , respectively, $\left.p<0.05 ; n=7\right)$, indicating robust memories for the training object location. In addition, a one-way ANOVA conducted on the time spent with the moved object indicated a significant main effect of treatment $\left(F_{(4,32)}=2.97, p=0.034\right)$. Fisher's LSD posthoc tests indicated that the DPN, $100 \mathrm{pg}$, and $1 \mathrm{ng}$ groups spent significantly more time with the moved object than the vehicle group, whereas the vehicle and $10 \mathrm{pg}$ groups did not differ from each other. Together, these data suggest that dorsal hippocampal infusion of $100 \mathrm{pg}$ or $1 \mathrm{ng}$ of ISP358-2 enhanced object placement memory consolidation.

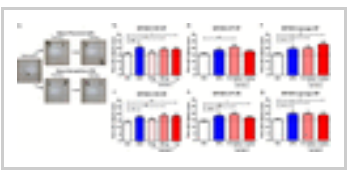

Figure 8. Behavioral assays. (a) Overview of the OR and OP testing procedures. When infused into the DH, DPN at the 100 pg and $1 \mathrm{ng} /$ hemisphere doses of ISP358-2 significantly increased the time that was spent with the moved (b) or novel (c) object relative to chance $\left(15 \mathrm{~s} ;{ }^{*} p<0.05 ;{ }^{* *} p<0.01\right)$ and vehicle $(\# p<0.05 ; \# \#<0.01)$, suggesting that ISP358-2 enhanced memory consolidation to a similar extent as the positive control DPN. When injected IP, DPN and $0.5 \mathrm{mg} / \mathrm{kg}$ ISP358-2 enhanced memory consolidation in the OP (d) and OR (e) tests (\#\#\#p<0.001). Five $\mathrm{mg} / \mathrm{kg}$ ISP358-2 also enhanced OP memory consolidation. Similarly, oral gavage treatments of 0.5 and $5 \mathrm{mg} / \mathrm{kg}$ ISP358-2 enhanced memory consolidation in the OP (f) and OR (g) tests. (a) Adapted from ref (38).

Results for object recognition (Figure 8c) were nearly identical. Neither the vehicle nor $10 \mathrm{pg}$ of ISP358-2 groups showed a preference for the novel object $\left(t s_{(9-10)}=1.08\right.$ and 0.88 , respectively, $\left.p>0.05 ; n=10-11\right)$. However, the DPN, $100 \mathrm{pg}$ of ISP358-2, and $1 \mathrm{ng}$ of ISP358-2 groups all spent significantly more time than chance with the novel object $\left(t s_{(9-10)}=2.35,3.16\right.$, and 1.08 , respectively, $\left.p<0.05 ; n=10-11\right)$. Moreover, the main effect of treatment was significant $\left(F_{(4,48)}=3.69, p=0.011\right)$, and posthoc tests confirmed that the DPN, $100 \mathrm{pg}$ of ISP358-2, and $1 \mathrm{ng}$ of ISP3582 groups, but not the $10 \mathrm{pg}$ of ISP358-2 group, differed significantly from vehicle. As with object placement, these data indicate that dorsal hippocampal infusion of $100 \mathrm{pg}$ or $1 \mathrm{ng}$ of ISP358-2, but not $10 \mathrm{pg}$ of ISP358-2, enhanced object recognition memory consolidation. 


\section{Intraperitoneal Injection}

We next used a new set of mice to investigate whether systemic administration of ISP358-2 also provide similar memory enhancing effects as intrahippocampal infusion (Figure 8d,e). Intraperitoneal (IP) injection is a common, reliable, and convenient systemic treatment in which the injected drug is absorbed into the blood vessels through the peritoneum.(30) Because the doses of the drugs for intrahippocampal infusion are much smaller than that needed to cross the blood-brain barrier, we examined a range of IP doses based on the cell-based assay and DH infusion results above and previous work showing that IP injections of $0.05 \mathrm{mg} / \mathrm{kg}$ DPN enhanced object recognition memory.(31) In our cell-based assays, the $\mathrm{EC}_{50}$ of ISP358-2 was approximately 10 times higher than that of DPN. Moreover, our behavioral tests showed that ISP358-2 enhances hippocampal memory at a concentration 10 times higher than DPN. Therefore, our IP doses of ISP358-2 were at least 10 times higher than DPN ( 0.5 and $5 \mathrm{mg} / \mathrm{kg}$ ). We thus tested four groups of mice as follows: vehicle (negative control), DPN (positive control), and two doses of ISP358-2 (0.5 and 5 $\mathrm{mg} / \mathrm{kg}$ ).

For object placement (Figure 8d), one-sample $t$-tests indicated that mice receiving vehicle did not show a preference for the moved object $\left(t_{(8)}=0.68, p>0.05 ; n=9\right)$. However, the DPN, $0.5 \mathrm{mg} / \mathrm{kg}$ ISP358-2, and $5 \mathrm{mg} / \mathrm{kg}$ ISP358-2 groups all spent significantly more time than chance with the moved object $\left(t s_{(9-1)}=3.20,3.93\right.$, and 2.78 , respectively, $p<$ $0.05 ; n=10-12)$, suggesting that systemic administration of ISP358-2 enhanced object placement memory consolidation. Moreover, the main effect of treatment was significant $\left(F_{(3,38)}=3.63, p=0.021\right)$, and posthoc tests showed that the $0.5 \mathrm{mg} / \mathrm{kg}$ ISP358-2 group differed significantly from vehicle. These data demonstrate that IP injection of ISP358-2 enhances spatial memory consolidation in a manner similar to dorsal hippocampal infusion.

Similar results were observed for object recognition (Figure 8e). One-sample $t$-test results showed that mice receiving vehicle did not spend significantly more time than chance with the novel object $\left(t_{(9)}=1.40, p>0.05 ; n=10\right)$. In contrast, the DPN and $0.5 \mathrm{mg} / \mathrm{kg}$ ISP358-2 groups exhibited a significant preference for the novel object relative to chance $\left(t s_{(8 \text { and11 })}=3.52\right.$ and 4.17 , respectively, $p<0.01 ; n=9$ and 12). There was also somewhat of a trend for the 5 $\mathrm{mg} / \mathrm{kg}$ ISP358-2 to prefer the novel object $\left(t_{(12)}=1.65, p=0.125 ; n=13\right)$. In addition, the main effect of treatment was significant $\left(F_{(3,40)}=5.05, p=0.005\right)$, and posthoc tests verified that the DPN, $0.5 \mathrm{mg} / \mathrm{kg} \mathrm{ISP358-2,} \mathrm{and} 5 \mathrm{mg} / \mathrm{kg}$ ISP358-2 groups differed significantly from the vehicle group. Together, the object placement and object recognition data suggest that IP administration of ISP358-2, particularly the $0.5 \mathrm{mg} / \mathrm{kg}$ dose, enhances object recognition and spatial memory consolidation similar to dorsal hippocampal infusion. Importantly, these data also demonstrate brain penetrance and behavioral efficacy in ovariectomized mice.

\section{Oral Gavage}

Given the mnemonic effectiveness of IP injection, we next assessed whether oral administration of ISP358-2 could enhance memory consolidation (Figure $8 \mathrm{f}, \mathrm{g}$ ). Oral gavage is a common procedure in scientific experiments delivering the drug directly into the stomach by means of a syringe.(32)Although it is highly effective and more accurate than other oral administration methods such as administration through delivery in food and/or water, it is more invasive and stressful.(33) Because we observed that IP injection of ISP358-2 enhanced hippocampal memory consolidation,

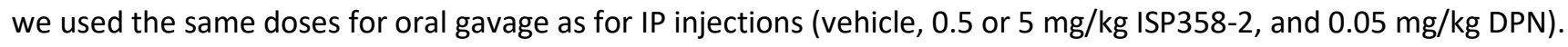

Similar results were observed for oral administration as were observed for IP injection ISP358-2. For object placement (Figure $8 \mathrm{f}$ ), one-sample $t$-test results showed that mice receiving vehicle did not spend significantly more time than


ISP358-2 groups all exhibited a significant preference for the moved object relative to chance $\left(t s_{(8-9)}=2.76,3.65,5.06\right.$, respectively, $p<0.05 ; n=9-10)$, suggesting that oral administration of ISP358-2 enhanced spatial memory consolidation. Also, one-way ANOVA showed that the main effect of treatment was significant $\left(F_{(3,33)}=5.04, p=\right.$ 0.006), and posthoc tests verified that the DPN, $0.5 \mathrm{mg} / \mathrm{kg}$ ISP358-2, and $5 \mathrm{mg} / \mathrm{kg}$ ISP358-2 groups differed significantly from the vehicle group. Likewise, for object recognition (Figure 8g), one-sample $t$-tests indicated that mice receiving vehicle did not show a preference for the novel object $\left(t_{(8)}=0.25, p>0.05 ; n=9\right)$. In contrast, the DPN, $0.5 \mathrm{mg} / \mathrm{kg}$ ISP358-2, and $5 \mathrm{mg} / \mathrm{kg}$ ISP358-2 groups all spent significantly more time with the novel object relative to chance $\left(t s_{(7-9)}=3.89,5.37\right.$, and 2.36, respectively, $\left.p<0.05 ; n=8-10\right)$. Moreover, the main effect of treatment was significant $\left(F_{(3,32)}=3.02, p=0.044\right)$, and posthoc tests showed that the DPN, $0.5 \mathrm{mg} / \mathrm{kg}$ ISP358-2, and $5 \mathrm{mg} / \mathrm{kg}$ ISP358-2 groups differed significantly from vehicle. Together, the object placement and object recognition behavior results 
demonstrate that oral administration of ISP358-2 enhances object recognition and spatial memory consolidation similar to dorsal hippocampal infusion and IP injection. These data also suggest the oral bioavailability of ISP358-2 in ovariectomized mice.

Finally, we collected preliminary data to assess the effectiveness of orally gavaged ISP358-2 on spatial memory consolidation in mice who experienced long-term estrogen deprivation. Mice that received ip injections of vehicle, DPN, or ISP358-2 above remained in our colony for 4 months after ovariectomy. They were then trained in the object placement task (using new objects) and then immediately given vehicle, DPN, or ISP358-2 via oral gavage in the same doses described above ( $n=9-12$ /group). Unlike mice gavaged within 1 month of ovariectomy (Figure 8f), DPN or ISP358-2 did not enhance spatial memory consolidation in mice treated within 4 months of ovariectomy (Supporting Information, Figure S5a). We then measured $\mathrm{ER} \alpha$ and $\mathrm{ER} \beta$ levels in the $\mathrm{DH}$ using Western blotting as per our previous work(34) (ER $\alpha, 1: 200$, Santa Cruz Biotechnology; ERß, 1:200, Santa Cruz Biotechnology); tissue was collected approximately 2 and 5 months after ovariectomy. Levels of ER $\beta$ were significantly reduced 5 months after ovariectomy relative to 2 months after ovariectomy (Supporting Information, Figure S5b; $t_{9}=2.46, p<0.05$ ). In contrast, levels of ER $\alpha$ did not change (Supporting Information, Figure S5c). These data suggest that DPN or ISP358-2 did not enhance memory after long-term ovariectomy because of the reduced levels of ER $\beta$. By extension, these data also support in vivo selectivity of ISP358-2 for ER $\beta$ because, if ISP358-2 enhanced memory via binding to ER $\alpha$, then it should have been able to enhance memory consolidation after long-term ovariectomy because ER $\alpha$ levels were not reduced. However, the fact that ER $\beta$ levels were reduced at a time at which ISP358-2 did not enhance memory supports our hypothesis that it regulates memory via ER $\beta$ and not ER $\alpha$.

\section{Assessment of Peripheral Pathology or Cell Proliferation Due to ISP358-2 Treatment}

In general, all the tissues from the 20 different specimens appeared similar. Heart: the cardiac tissues were all unremarkable. The ventricular walls were intact and normal thickness. The atrial walls were intact with normal thickness. There was no evidence of congenital defects such as myofiber disarray or ischemic heart disease or ischemic injury. There was no evidence of inflammation or myocarditis. Kidney: The kidneys were all unremarkable. The glomeruli were intact. The tubules appeared normal. There was no evidence of inflammation involving any of the structures of the kidneys. Liver: The general architecture of the liver was intact and normal appearing with large portal-types veins running together with hepatic ducts and hepatic arteries. The central veins were present and normal appearing. A generalized appearance of low grade/mild ischemic injury was present in all samples. This seemed nonspecific, was appreciated in all specimens, and could be secondary to early ischemic damage or autolysis that occurred post mortem. In several animals, small foci of cellular necrosis were observed likely secondary to ischemia. Two animals showed areas with mild, low grade inflammation that was small and focal. One animal (R15-IP$24 \mathrm{~V}$ ) had multifocal areas of an organized inflammatory infiltrate composed primarily of mononuclear lymphocytes. Overall, there was no evidence of acute inflammation composed of neutrophils or damage to structures in the liver, such as hepatic ducts. Bloodwork chemistry and hematology data (Supporting Information, Figure S7) for treated animals did not show significant deviations from expected reference ranges, relative to vehicle, except for modest effects due to hemolysis that was likely due to sample collection via cardia puncture. Finally, while $\mathrm{E}_{2}$ caused statistically significant proliferation of MCF-7 breast cancer cells at doses of 10, 100, and $1000 \mathrm{nM}$ neither ISP358-2 nor DPN showed any significant proliferation relative to untreated control cells (Figure S8).

\section{Discussion}

ER $\beta$ has previously been pursued as a drug target for a wide range of conditions, including anxiety, depression, schizophrenia, and Alzheimer's disease, with representative ER $\beta$ drug lead agonist compounds shown in Figure 1a.(35) Compounds presented herein (Table 1) differ from these previously reported compounds in that they are more selective for $E R \beta$ over $E R \alpha(\sim 750$-fold) and in that they are A-C estrogens that resemble the native $17 \beta$ estradiol molecule, lacking only the $B$ and $D$ rings.

\section{Structure-Activity Relationship for the A-C Estrogens}

The binding affinity of 4-(4-substituted cyclohexyl)phenols were assessed in a TR-FRET ER $\beta$ binding assay (Table 1 and Figure 2). In particular, compounds bearing a hydroxymethyl functionality attached to the cyclohexyl core showed higher affinities, in the range 20-200 nM. Of the two components in the 2:1 mixture of cis- and trans- 
stereoisomers $15 / 16\left(\mathrm{EC}_{50}=180 \mathrm{nM}\right)$, the trans-isomer was found to be more potent (ISP358-2, $\left.\mathrm{EC}_{50}=24 \mathrm{nM}\right)$ than the mixture. Introduction of unsaturation within the six-membered ring $\left(18, E_{50}=49 \mathrm{nM}\right)$ did not greatly reduce the binding affinity compared to ISP358-2; however, conformational restriction, such as is present in the exocyclic allylic alcohol, reduced affinity $\left(24, \mathrm{EC}_{50}=680 \mathrm{nM}\right)$. The presence of a third hydroxyl group led to greatly reduced binding affinity $\left(12, \mathrm{EC}_{50}=2700 \mathrm{nM}\right)$. Finally, varying the distance between the phenolic $\mathrm{OH}$ and the aliphatic alcohol group gave a larger range of binding affinities $\left(2, \mathrm{EC}_{50}=7,520 \mathrm{nM} ; 25, \mathrm{EC}_{50}=11 \mathrm{nM}\right)$. Those analogues having $\mathrm{EC}_{50}$ values $<200 \mathrm{nM}$ were further tested in a cell-based transcriptional activation assay to evaluate their ER $\beta$ selectivity both in terms of binding affinity and of efficacy in activating transcription in a biologically relevant system. The transstereoisomer ISP358-2, 8, 18, and 25 exhibited similar ERB agonist potencies (EC F0 $_{50}$ 30-75 nM) in the TR-FRET assay, but ISP358-2 stands out as being the most potent and selective in this more biologically relevant cell-based functional assay. Interestingly, the hydroxyethyl analogue was less potent in the cell-based functional assay $\left(\mathbf{2 5}, \mathrm{EC}_{50}=75\right.$ vs 11 $\mathrm{nM})$.

The potency differences observed in the assays may be due to the nature of what the assays measure. The TR-FRET assay in Figure 2 measures only displacement of a fluorescently labeled estradiol ligand from the ligand binding domain (LBD), which reflects binding affinity for the ligand that competitively displaces the fluorescent probe. In contrast, the cell-based assay is more complicated and measures the entire sequence of molecular events leading to transcriptional activation. This sequence of events involves a series of conformational changes (e.g., a rotation of helix-12 of the ligand binding domain) that are triggered by the initial hormone binding.(36) The protein conformational change in the estrogen receptor induced by agonist binding results in recruitment of a coactivator protein and also triggers protein dimerization, ultimately resulting in DNA binding and transcriptional activation. Additional interactions between the aliphatic hydroxyl group and the His475 residue of ER $\beta$ plays a role in the conformational change involving nearby helix-12, which would be reflected in $\mathrm{EC}_{50}$ values in the cell-based functional assay (Figure 5) but not in the TR-FRET binding assay (Figure 2).

All compounds tested showed no significant $E R \beta$ or ER $\alpha$ antagonist activity ( $E C_{50}>10000 \mathrm{nM}$ ), thus also demonstrating their selectivity as agonist vs antagonist activity (Table 1 and Figure $5 c$,d). Of the ER $\beta$ agonists, ISP3582 was the most selective, with $\sim 750$-fold agonist selectivity for ER $\beta$ over ER $\alpha$ in the cell-based functional assay, but it had only modest selectivity in the TR-FRET binding assay (Figure $2 b$ ).

\section{Assay Differences Suggest Mechanism for Isoform Selectivity}

As mentioned above, the cell-based assay for ISP358-2 indicates that it is $\sim 750$-fold selective for ER $\beta$ agonist activity over ER $\alpha$ agonist activity (Figure 5a,b), whereas the TR-FRET binding assay shows more modest 12-fold selectivity for ER $\beta$ (Figure $2 b$ ). This could be because the TR-FRET binding assay simply measures binding affinity (to an isolated LBD), whereas the cell-based assay measures transcription that is induced by agonist binding to a full-length and native $E R \beta$, which causes a productive conformational change in ER $\beta$ that includes rotation of helix-12 (leading to recruitment of coactivators, dimerization, DNA binding, and then transcriptional activation). To test the hypothesis that assay differences are due to these downstream activation events, two other assays were performed. In a first assay, transcriptional activation was measured in a different cell-based assay, now using an unnatural chimeric receptor (ER LBD fused to a GLA4 DBD). In this assay (Figure 3b), there was a modest 2.6-fold selectivity for ER $\beta$. In a second assay, ability of agonist binding to recruit binding of a coactivator peptide to the ER LBD was measured (Figure 4a). In this assay, 15 -fold selectivity for ER $\beta$ was observed (Figure 4c). Thus, ER $\beta$ versus ER $\alpha$ selectivity for ISP358-2 varies significantly based on how well the assay incorporates native downstream activation events that occur subsequent to binding to the ER $\beta$ binding pocket as a result of hormone-induced conformational changes. It therefore appears that the significant ER $\beta$ versus ER $\alpha$ selectivity shown by ISP358-2 is not just a function of binding affinity for the ER $\beta$ receptor (as measured in the TR-FRET assay in Figure 2b) but rather is a function of the ability to induce the productive conformational change that leads to downstream activation of transcription (Figure 5a).

Consistent with the above hypothesis that ISP358-2 potency and selectivity are related to its ability to drive a productive conformational change, docking studies show that ISP358-2 docks into the ER $\beta$ active site in a conformation that differs significantly from that for the ER $\alpha$ binding site. Key differences occur where the estrogen $C$ ring is normally located (Figure $7 \mathrm{c}, \mathrm{f}, \mathrm{g}$ ), thereby affecting positioning of the aliphatic hydroxyl group that interacts with the His524 and/or Gly472 (backbone carbonyl) residues (Figure 7f,g) in the region known to be important for driving the helix-12 conformational change that permits binding of coactivator. The ER $\beta$ hydrophobic interactions include $\pi-$ 
$\pi$ stacking between Phe356 and the ISP358-2 phenol ring, along with Ala302, Leu298, Leu476, and Ile373 that constrain the cyclohexyl ring and its attached hydroxymethyl methyl group in the " $\mathrm{C}$ ring" region (Figure $1 \mathrm{~d}$ ). These unique hydrophobic interactions in the ER $\beta$ active site may be what drives the $90^{\circ}$ rotation of the $C$ (cyclohexane) ring of ISP358-2 relative to the phenol ring in the ER $\beta$ pocket relative to the ER $\alpha$ pocket (Figure $7 b, c$ ), and in this way, they could affect the adjacent coactivator pocket. This region of the $17 \beta$-estradiol binding pocket is known to affect the accessibility and structure of the coactivator binding pocket and so could be the reason for the large differences in agonist activity that were observed for ISP358-2. Future structural characterization studies are being planned to address this question.

\section{Druggability and Preliminary Safety Toxicity}

While ISP358-2 binds to ER and activates transcription, it shows no significant off-target activity with seven other nuclear hormone receptors (Figure 3a). ISP358-2 also showed no significant activity against the heart potassium ion channel hERG (Supporting Information, Figure S3b) and no significant inhibition of the major drug metabolizing cytochrome P450 enzymes, CYP2D6, CYP3A4, CYP2C9, and CYP1A2 (Figure 6). ISP358-2 was also reasonably soluble, showing no aggregation in nephelometry assays (Supporting Information, Figure S3a).

To assess the potential of ISP358-2 to stimulate breast cancer cell growth, MTT assays with MCF-7 human breast cancer cells were performed (Supporting Information, Figure S8). No significant changes in the growth of MCF-7 cells were observed following treatment at any concentration of the ER $\beta$ agonists ISP358-2 or DPN compared to untreated controls (Supporting Information, Figure S8b,c). However, the proliferation of MCF-7 cells treated with 1, 0.1, or 0.01 $\mu \mathrm{M} \mathrm{E}_{2}$ was significantly increased ( $n=3 ; p<0.02,0.05,0.003$, respectively) compared to untreated controls (Supporting Information, Figure S8a). Furthermore, cell proliferation was significantly lower ( $n=3 ; p \leq 0.04$ for both compounds) in comparison to positive control MCF-7 cells treated with $0.01 \mu \mathrm{M} \mathrm{E}_{2}$.

To assess potential peripheral pathology due to ISP358-2 treatment, a histological analysis of tissue slices of treated animals was performed (Supporting Information, Figure S6). Overall, tissue changes due to treatment were unremarkable. Mild, global ischemic changes were noted in the livers of all animals. It is difficult to assign a specific pattern or significance to this finding. These changes likely represent hypoperfusion and subsequent mild ischemic changes in the post mortem period. One animal showed organized lymphoid hyperplasia in the liver. None of the animals demonstrated any significant pathological changes in the heart or kidney.

\section{In Vivo Efficacy}

A single post-training systemic injection or intracranial infusion of $E_{2}$ or agonists of ER $\alpha$ or ER $\beta$, including DPN, enhances memory consolidation in the object recognition and object placement via rapid nonclassical (aka, nongenomic) effects. $(6,34,38-40,42,61)$ These compounds activate numerous cell signaling pathways in the dorsal hippocampus within $5 \mathrm{~min}$ of dorsal hippocampal infusion, and pharmacological inhibition of this activation prevents $E_{2}$, DPN, and the ER $\alpha$ agonist PPT from enhancing memory. $(6,34,58)$ The nonclassical nature of these effects have been demonstrated in studies showing that they require interactions among $E R \alpha, E R \beta$, and metabotropic glutamate receptors at the plasma membrane.(34) In the present study, in vivo behavioral assays measuring object placement or object recognition (Figure 8a) showed efficacy for all three routes of administration: microinfusion into the dorsal hippocampus, intraperitoneal injection, or oral gavage (Figure 8). Thus, ISP358-2 can enhance object recognition and spatial memory consolidation in ovariectomized female mice. Intrahippocampal infusion of $100 \mathrm{pg}$ and $1 \mathrm{ng}$ of ISP3582 enhanced memory consolidation in the object recognition and object placement tasks as effectively as the ER $\beta$ agonist DPN (Figure 8b,c). In systemic administration experiments, $0.5 \mathrm{mg} / \mathrm{kg}$ ISP358-2 most effectively enhanced consolidation in both tasks when delivered intraperitoneally (Figure $8 \mathrm{~d}$,e), whereas $5 \mathrm{mg} / \mathrm{kg}$ ISP358-2 was most effective via oral gavage (Figure $8 \mathrm{f}, \mathrm{g}$ ). These data are consistent with previous findings showing that intrahippocampal or systemic administration of the ER $\beta$ agonists DPN or WAY200070 enhance hippocampal-dependent memory in ovariectomized rats and mice in tasks including object recognition, object placement, and the radial arm maze.(3,34,39-42) As such, ISP358-2 mimics the memory-enhancing effects of other ER $\beta$ agonists with different chemical structures and could potentially be used to reduce memory dysfunction in numerous neuropsychiatric conditions for which women are at increased risk, including AD, depression, and schizophrenia.(43) Moreover, women are at greater risk of anxiety disorders than men,(43) and DPN decreases anxiety-related behaviors among rodents tested in the open field and elevated plus maze tasks. $(44,45)$ Thus, ISP358-2 has the potential to not only 
facilitate memory consolidation but also to reduce anxiety. Although promising, numerous issues remain to be addressed in future studies, including the extent to which the beneficial effects of ISP358-2 generalize to males, older subjects, rodent models of $A D$ and other disorders, and other forms of memory.

Finally, while it was observed that ISP358-2 is highly selective for ER $\beta$ over ER $\alpha$ in the more biologically relevant cellbased assay, it is not known if it has this same selectivity for ER $\beta$ in vivo. However, our preliminary studies have shown a correlation between behavioral results and levels of ER $\beta$ in the brain, consistent with the effect being related to ER $\beta$ agonist activity (Supporting Information, Figure S5). While the observed behavioral effects are consistent with the predicted blood-brain barrier (BBB) penetration (Supporting Information, Figure S10) and subsequent activation of ER $\beta$, future studies will be directed toward determining the pharmacological mechanism of ISP358-2 in vivo, including in vivo studies of isoform selectivity, effects on signaling cascades, and neural morphology changes in the brain as well as pharmacokinetics and pharmacodynamics.

\section{Conclusion}

The results of the current study demonstrate that our lead compound, ISP358-2, is selective for ER $\beta$ and shows no obvious signs of peripheral toxicity. Importantly, ISP358-2 also enhances multiple types of memory dependent on the hippocampus, a brain region involved in numerous disorders including $A D$, depression, and schizophrenia. $(43,46)$ ISP358-2 is distinct from previously reported ER $\beta$ agonists in that it has higher selectivity for $E R \beta$ over ER $\alpha$ and in that it more closely resembles that naturally occurring $17 \beta$-estradiol molecule (Figure $1 \mathrm{~d}$ ) as an A-C estrogen. Our studies also demonstrated biological efficacy in behavioral assays that were performed via three routes of administration: direct dorsal hippocampal infusion, intraperitoneal injection, and oral gavage, the latter two of which illustrate brain penetrance of the effective doses (Figure 8). Overall, these findings suggest that the novel ER $\beta$ agonist ISP358-2 could be a promising drug candidate for enhancing memory in a variety of disorders characterized by memory dysfunction that occurs under low estrogen conditions, such as menopause.

\section{Experimental Section}

\section{Compound Synthesis}

All the chemicals were purchased from Sigma-Aldrich, Matrix Scientific, or Alfa Aesar and used as received. Reactions with moisture- or air-sensitive reagents were conducted under an inert atmosphere of nitrogen in oven-dried glassware with anhydrous solvents. Reactions were followed by TLC on precoated silica plates $\left(60 \AA\right.$, $F_{254}$, EMD Chemicals Inc.) and were visualized by UV lamp (UVGL-25, 254/365 nm). Flash column chromatography was performed by using flash silica gel (32-63 $\mu$ ). NMR spectra were recorded on Varian Unity Inova $400 \mathrm{MHz}$ instrument. $\mathrm{CDCl}_{3}$, acetone- $d_{6}$, and $\mathrm{CD}_{3} \mathrm{OD}$ were purchased from Cambridge Isotope Laboratories. ${ }^{1} \mathrm{H}$ NMR spectra were calibrated to $\delta=7.26 \mathrm{ppm}$ for residual $\mathrm{CHCl}_{3}, \delta=2.05 \mathrm{ppm}$ for acetone- $d_{6}$, and $\delta=3.30 \mathrm{ppm}$ for residual $\mathrm{CD}_{3} \mathrm{OD}-d_{3 .}{ }^{13} \mathrm{C} \mathrm{NMR}$ spectra were calibrated from the central peak at $\delta=77.23 \mathrm{ppm}$ for $\mathrm{CDCl}_{3}, \delta=29.92 \mathrm{ppm}$ for acetone- $d_{6}$ and $\delta=49.00$ ppm for $\mathrm{CD}_{3} \mathrm{OD}$. Purity of all compounds was $>95 \%$, determined with chromatography and NMR.

\section{trans-4-(4-Hydroxycyclohexyl)phenol (2)}



To a solution of $1(0.200 \mathrm{~g}, 5.30 \mathrm{mmol})$ in anhydrous methanol $(15 \mathrm{~mL})$ at room temperature was added solid $\mathrm{NaBH}_{4}(0.400 \mathrm{~g}, 10.6 \mathrm{mmol})$. The mixture was stirred for $3 \mathrm{~h}$ and then extracted with several times with ethyl acetate. The combined extracts were concentrated to give $2(0.181 \mathrm{~g}, 90 \%)$ as a colorless solid; mp $196-208^{\circ} \mathrm{C}$. ${ }^{1} \mathrm{H}$ NMR $(400$ $\left.\mathrm{MHz}, \mathrm{CD}_{3} \mathrm{OD}\right) \delta 7.00$ and $6.67\left(\mathrm{AA}^{\prime} X^{\prime} X^{\prime}, J_{\mathrm{AX}}=8.7 \mathrm{~Hz}, 4 \mathrm{H}\right), 3.61-3.53(\mathrm{~m}, 1 \mathrm{H}), 2.38(\mathrm{tt}, J=11.8,3.4 \mathrm{~Hz}, 1 \mathrm{H}), 2.05-1.98(\mathrm{~m}$, $2 \mathrm{H}), 1.87-1.78(\mathrm{~m}, 2 \mathrm{H}), 1.56-1.30(\mathrm{~m}, 4 \mathrm{H}) \mathrm{ppm} .{ }^{13} \mathrm{C} \mathrm{NMR}\left(100 \mathrm{MHz}, \mathrm{CD}_{3} \mathrm{OD}\right) \delta$ 156.6, 139.2, 128.7, 116.1, 71.4, 49.3, 44.3, 36.9, 34.2 ppm. HRMS $\mathrm{m} / \mathrm{z} 191.1077$ [calcd for $\mathrm{C}_{12} \mathrm{H}_{15} \mathrm{O}_{2}^{-}\left(\mathrm{M}-\mathrm{H}^{+}\right)$191.1077]. 


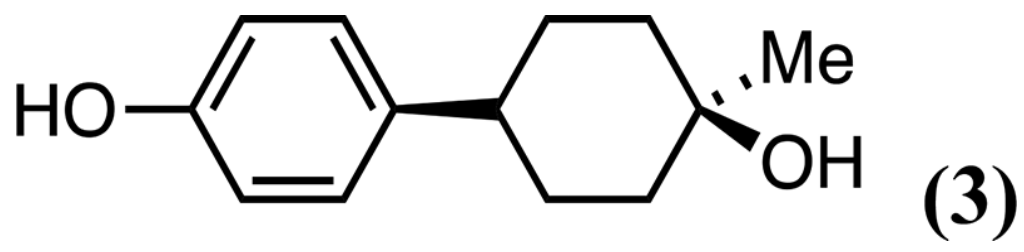

To a solution of $1(0.100 \mathrm{~g}, 0.526 \mathrm{mmol})$ in dry ether $(20 \mathrm{~mL})$ at $-78{ }^{\circ} \mathrm{C}$ under $\mathrm{N}_{2}$ was slowly added a solution of methyllithium-lithium bromide complex $(1.5 \mathrm{M}$ in ether, $0.78 \mathrm{~mL}, 1.2 \mathrm{mmol})$. The mixture was stirred at $-78^{\circ} \mathrm{C}$ for 30 min, warmed to room temperature, and stirred for another $1 \mathrm{~h}$. The mixture was cooled to $0{ }^{\circ} \mathrm{C}$ and quenched with water. The mixture was extracted several times with ether and the combined extracts dried $\left(\mathrm{Na}_{2} \mathrm{SO}_{4}\right)$ and concentrated. The residue was purified by column chromatography $\left(\mathrm{SiO}_{2}\right.$, hexanes-ethyl acetate $\left.=4: 1\right)$ to give $3(0.040 \mathrm{~g}, 37 \%)$ as a colorless solid; $\mathrm{mp} 126-131^{\circ} \mathrm{C}$. ${ }^{1} \mathrm{H}$ NMR $\left(400 \mathrm{MHz}, \mathrm{CD}_{3} \mathrm{OD}\right) \delta 7.03$ and $6.67\left(\mathrm{AA}^{\prime} \mathrm{XX}^{\prime}, \mathrm{J}_{\mathrm{AX}}=8.3\right.$ $\mathrm{Hz}, 4 \mathrm{H}), 2.35(\mathrm{tt}, J=12.4,3.6 \mathrm{~Hz}, 1 \mathrm{H}), 1.87-1.69(\mathrm{~m}, 4 \mathrm{H}), 1.61-1.44(\mathrm{~m}, 4 \mathrm{H}) 1.21(\mathrm{~s}, 3 \mathrm{H}) .{ }^{13} \mathrm{C} \mathrm{NMR}\left(100 \mathrm{MHz}, \mathrm{CD}_{3} \mathrm{OD}\right) \delta$ $156.5,140.0,128.8,116.1,69.5,44.5,40.0,31.9,31.1 \mathrm{ppm}$. HRMS $\mathrm{m} / \mathrm{z} 205.1234$ [calcd for $\mathrm{C}_{13} \mathrm{H}_{17} \mathrm{O}_{2}{ }^{-}\left(\mathrm{M}-\mathrm{H}^{+}\right)$ 205.1234]. Anal. Calcd for $\mathrm{C}_{13} \mathrm{H}_{18} \mathrm{O}_{2}: \mathrm{C}, 75.69 ; \mathrm{H}$ 8.79. Found: $\mathrm{C}, 75.33 ; \mathrm{H}, 8.83$.

\section{4-(4-Hydroxyphenyl)cyclohexanone Oxime (4)}

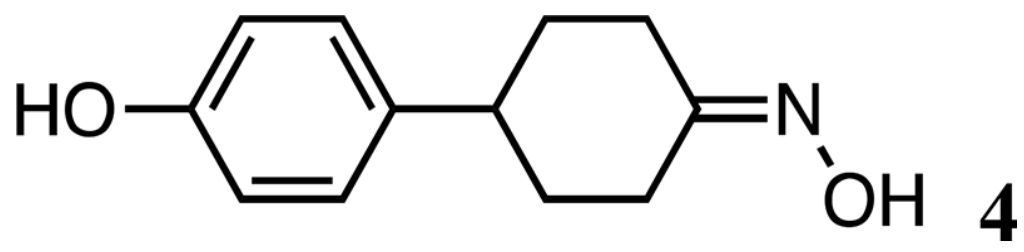

To a solution of $1(0.050 \mathrm{~g}, 0.26 \mathrm{mmol})$ in ethanol $(10 \mathrm{~mL})$ were added Amberlyst $(0.060 \mathrm{~g})$ and hydroxylamine hydrochloride $(0.039 \mathrm{~g}, 0.560 \mathrm{mmol})$. The mixture was stirred at room temperature for $2 \mathrm{~h}$ and then filtered. The filtrate was concentrated and extracted several times with ethyl acetate. The combined organic extracts were washed with water, dried $\left(\mathrm{MgSO}_{4}\right)$, and concentrated to give 4 as a colorless solid $(0.037 \mathrm{~g}, 70 \%) ; \mathrm{mp} 171-174{ }^{\circ} \mathrm{C} .{ }^{1} \mathrm{H}$ NMR $\left(400 \mathrm{MHz}, \mathrm{CD}_{3} \mathrm{OD}\right) \delta 7.00$ and $6.69\left(\mathrm{AA}^{\prime} \mathrm{XX}^{\prime}, J_{\mathrm{AX}}=8.2 \mathrm{~Hz}, 4 \mathrm{H}\right), 3.39$ (broad d, $\left.J=13.5 \mathrm{~Hz}, 1 \mathrm{H}\right), 2.67(\mathrm{t}, J=12.8 \mathrm{~Hz}, 1 \mathrm{H})$, 2.41 (broad d, $J=14.0 \mathrm{~Hz}, 1 \mathrm{H}$ ), $2.20(\mathrm{td}, J=14.6,5.4 \mathrm{~Hz}, 1 \mathrm{H}$ ), 1.93 (broad t, $J=15.8 \mathrm{~Hz}, 2 \mathrm{H}), 1.81(\mathrm{td}, J=14.0,5.2 \mathrm{~Hz}$, 1H), 1.61-1.42 (m, 2H) ppm. $\left.{ }^{13} \mathrm{C} \mathrm{NMR} \mathrm{(100} \mathrm{MHz,} \mathrm{CD}_{3} \mathrm{OD}\right) \delta 160.8,156.7,138.3,128.6,116.2,44.1,35.8,34.6,32.8$, 25.1 ppm. Anal. Calcd for $\mathrm{C}_{12} \mathrm{H}_{15} \mathrm{NO}_{2}$ : C, 70.22; H 7.36; N, 6.83. Found: C, 69.93; H, 7.36; N, 6.63.

\section{4-(4-t-Butyldimethylsilyloxyphenyl)cyclohexan-1-one (5)}

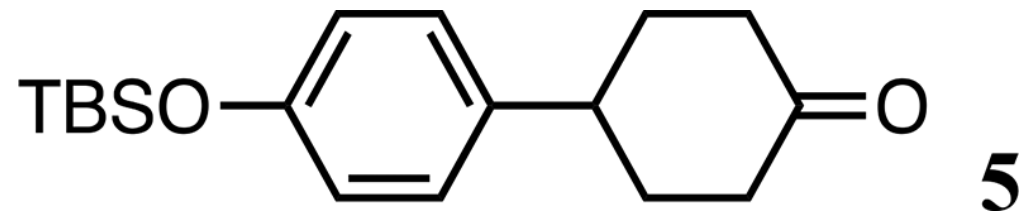

To a solution of $1(0.500 \mathrm{~g}, 2.62 \mathrm{mmol})$ in anhydrous $\mathrm{CH}_{2} \mathrm{Cl}_{2}(30 \mathrm{~mL})$ at $0{ }^{\circ} \mathrm{C}$ under $\mathrm{N}_{2}$ was added imidazole $(0.357 \mathrm{~g}$, $5.24 \mathrm{mmol})$. After $30 \mathrm{~min}, t$-butyldimethylsilyl chloride $(0.594 \mathrm{~g}, 3.94 \mathrm{mmol}$ ) was added and the mixture was gradually warmed to room temperature overnight. The resulting mixture was diluted with brine $(25 \mathrm{~mL})$ and extracted several times with $\mathrm{CH}_{2} \mathrm{Cl}_{2}$. The combined organic extracts were dried $\left(\mathrm{Na}_{2} \mathrm{SO}_{4}\right)$ and concentrated. The residue was purified by column chromatography $\left(\mathrm{SiO}_{2}\right.$, hexanes-ethyl acetate $\left.=9: 1\right)$ to give $\mathbf{5}(0.664,83 \%)$ as a colorless solid; $\mathrm{mp}$ 39-42 ${ }^{\circ} \mathrm{C} .{ }^{1} \mathrm{H}$ NMR $\left(400 \mathrm{MHz}, \mathrm{CDCl}_{3}\right) \delta 7.08$ and $6.78\left(\mathrm{AA}^{\prime} \mathrm{XX}^{\prime}, \mathrm{J}_{\mathrm{AX}}=8.4 \mathrm{~Hz}, 4 \mathrm{H}\right), 2.96(\mathrm{t}, \mathrm{J}=12.3 \mathrm{~Hz}, 1 \mathrm{H}), 2.56-2.40(\mathrm{~m}, 4 \mathrm{H})$, 2.25-2.14, (m, 2H), 1.97-1.82 (m, $2 \mathrm{H}), 0.98(\mathrm{~s}, 9 \mathrm{H}), 0.19(\mathrm{~s}, 6 \mathrm{H}) \mathrm{ppm} .{ }^{13} \mathrm{C} \mathrm{NMR}\left(100 \mathrm{MHz}, \mathrm{CDCl}_{3}\right) \delta 211.6,154.3,137.7$, $127.7,120.1,42.2,41.6,34.6,25.9,18.4,-4.2 \mathrm{ppm}$. 


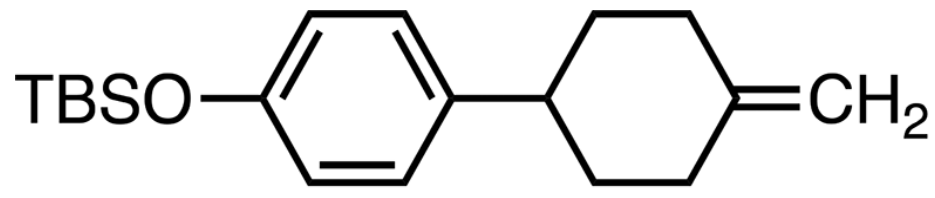

To a solution of methyltriphenylphosphonium bromide $(0.836 \mathrm{~g}, 2.34 \mathrm{mmol})$ in dry THF $(20 \mathrm{~mL})$ at $-10^{\circ} \mathrm{C}$ under $\mathrm{N}_{2}$ was slowly added a solution of $n$-butyllithium (1.6 M in hexane, $1.50 \mathrm{~mL}, 2.4 \mathrm{mmol}$ ). After $30 \mathrm{~min}$, a solution of $5(0.502 \mathrm{~g}, 1.17 \mathrm{mmol})$ in dry THF $(8 \mathrm{~mL})$ was added dropwise. The reaction mixture was slowly warmed to room temperature and stirred overnight. After this time, the mixture was diluted with water $(20 \mathrm{~mL})$, extracted several times with ethyl acetate, and the combined extracts were dried $\left(\mathrm{Na}_{2} \mathrm{SO}_{4}\right)$ and concentrated. Purification of the crude residue by column chromatography $\left(\mathrm{SiO}_{2}\right.$, hexanes-ethyl acetate $\left.=9: 1\right)$ gave $6(1.678 \mathrm{~g}, 84 \%)$ as a colorless oil. ${ }^{1} \mathrm{H}$ $\operatorname{NMR}\left(400 \mathrm{MHz}, \mathrm{CDCl}_{3}\right) \delta 7.06$ and $6.77\left(\mathrm{AA}^{\prime} \mathrm{XX}^{\prime}, \mathrm{J}_{\mathrm{AX}}=8.3 \mathrm{~Hz}, 4 \mathrm{H}\right), 4.68(\mathrm{~s}, 2 \mathrm{H}), 2.62(\mathrm{tt}, J=12.1,3.4 \mathrm{~Hz}, 1 \mathrm{H}), 2.42$ (broad $\mathrm{d}, J=13.5 \mathrm{~Hz}, 2 \mathrm{H}), 2.18$ (broad t, $J=13.2,2 \mathrm{H}), 2.00-1.93(\mathrm{~m}, 2 \mathrm{H}), 1.57-1.45(\mathrm{~m}, 2 \mathrm{H}), 0.99(\mathrm{~s}, 9 \mathrm{H}), 0.20(\mathrm{~s}, 6 \mathrm{H}) \mathrm{ppm} .{ }^{13} \mathrm{C}$ NMR $\left(100 \mathrm{MHz}, \mathrm{CDCl}_{3}\right) \delta 153.9,149.2,139.8,127.8,119.9,107.4,43.5,35.9,35.4,25.9,18.4,-4.2 \mathrm{ppm}$. Anal. Calcd for $\mathrm{C}_{19} \mathrm{H}_{30} \mathrm{O}_{2} \mathrm{Si}: \mathrm{C}, 75.43 ; \mathrm{H}, 9.99$. Found: $\mathrm{C}, 75.71 ; \mathrm{H}, 10.02$.

\section{4-(4-Hydroxyphenyl)methylenecyclohexane (7)}
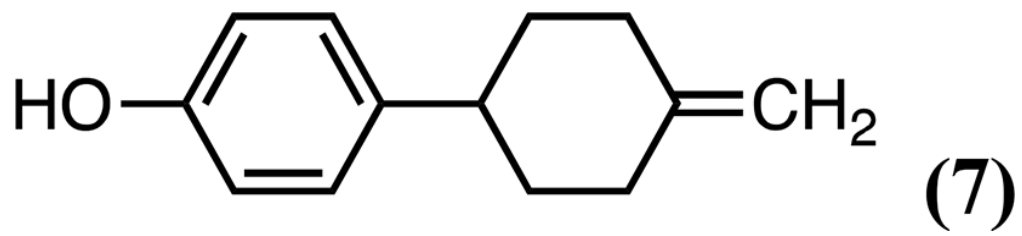

To a solution of $6(0.739 \mathrm{~g}, 0.244 \mathrm{mmol})$ in anhydrous THF $(20 \mathrm{~mL})$ was added a solution of TBAF (1 M in THF, $9.8 \mathrm{~mL}$, $9.8 \mathrm{mmol}$ ). The mixture was heated at reflux for $5 \mathrm{~h}$. After cooling, the solution was partitioned between ethyl acetate and water, and the aqueous layer was extracted several times with ethyl acetate. The combined organic layers were washed with brine, dried $\left(\mathrm{Na}_{2} \mathrm{SO}_{4}\right)$, and concentrated. Purification of the residue by column chromatography $\left(\mathrm{SiO}_{2}\right.$, hexanes-ethyl acetate $=4: 1)$ gave $7(0.379 \mathrm{~g}, 83 \%)$ as a colorless solid; mp 82-84 ${ }^{\circ} \mathrm{C}$. ${ }^{1} \mathrm{H}$ NMR $\left(400 \mathrm{MHz}, \mathrm{CD}_{3} \mathrm{OD}\right) \delta 6.99$ and $6.67\left(\mathrm{AA}^{\prime} X X^{\prime}, J_{A B}=8.5 \mathrm{~Hz}, 4 \mathrm{H}\right), 4.63(\mathrm{t}, J=1.7 \mathrm{~Hz}, 2 \mathrm{H}), 2.57(\mathrm{tt}, J=12.3,4.3 \mathrm{~Hz}, 1 \mathrm{H}), 2.41-2.33(\mathrm{~m}, 2 \mathrm{H}), 2.22-2.11$ (m, 2H), 1.94-1.85 (m, 2H), 1.45 (qd, $J=12.3,4.3 \mathrm{~Hz}, 2 \mathrm{H}) .{ }^{13} \mathrm{C}$ NMR $\left(100 \mathrm{MHz}, \mathrm{CD}_{3} \mathrm{OD}\right) \delta 156.6,150.3,139.3,128.8$, 116.2, 107.8, 44.8, 37.3, 36.4 ppm. HRMS $m / z 187.1128$ [calcd for $\mathrm{C}_{13} \mathrm{H}_{15} \mathrm{O}^{-}\left(\mathrm{M}-\mathrm{H}^{+}\right)$187.1128]. Anal. Calcd for $\mathrm{C}_{13} \mathrm{H}_{16} \mathrm{O}_{2}$ : C, 82.93; H 8.57. Found: C, 82.71; $\mathrm{H}, 8.58$.

4-(4-Methylcyclohexyl)phenol (8)

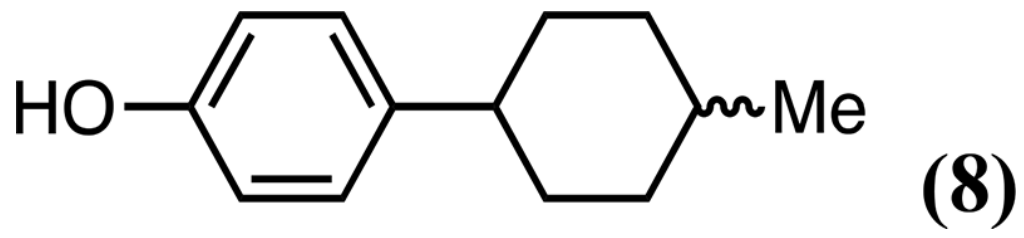

To a solution of $7(0.150 \mathrm{~g}, 0.797 \mathrm{mmol})$ in methanol $(10 \mathrm{~mL})$ was added $10 \% \mathrm{Pd} / \mathrm{C}(85 \mathrm{mg}, 10 \mathrm{~mol} \%)$. The mixtures was stirred under a balloon filled with $\mathrm{H}_{2}$, at room temperature, for $12 \mathrm{~h}$. The reaction mixture was filtered through a pad of Celite, dried $\left(\mathrm{Na}_{2} \mathrm{SO}_{4}\right)$, and concentrated. The residue was purified by column chromatography $\left(\mathrm{SiO}_{2}\right.$, hexanesethyl acetate $=4: 1)$ to give $8(0.121 \mathrm{~g}, 80 \%)$ as a colorless solid. This was determined to be a mixture of cis- and transstereoisomers by ${ }^{1} \mathrm{H}$ NMR spectroscopy; mp 93-99 ${ }^{\circ} \mathrm{C}$. ${ }^{1} \mathrm{H}$ NMR $\left(400 \mathrm{MHz}, \mathrm{CD}_{3} \mathrm{OD}\right) \delta 7.05-6.96(\mathrm{~m}, 2 \mathrm{H}), 6.70-6.64(\mathrm{~m}$, $2 \mathrm{H}), 2.48-2.28(\mathrm{~m}, 1 \mathrm{H}), 1.83-1.34(\mathrm{~m}, 8 \mathrm{H}), 1.13-1.04(\mathrm{~m}, 1 \mathrm{H}), 1.03(\mathrm{~d}, J=7.2 \mathrm{~Hz}, 1 \mathrm{H}), 0.92(\mathrm{~d}, J=6.6 \mathrm{~Hz}, 2 \mathrm{H}) .{ }^{13} \mathrm{C} N M R$ $\left(100 \mathrm{MHz}, \mathrm{CD}_{3} \mathrm{OD}\right) \mathrm{d} 156.3,140.0,128.6,116.0,44.7,36.9,35.9,33.7,33.1,30.1,23.1 \mathrm{ppm}$. 


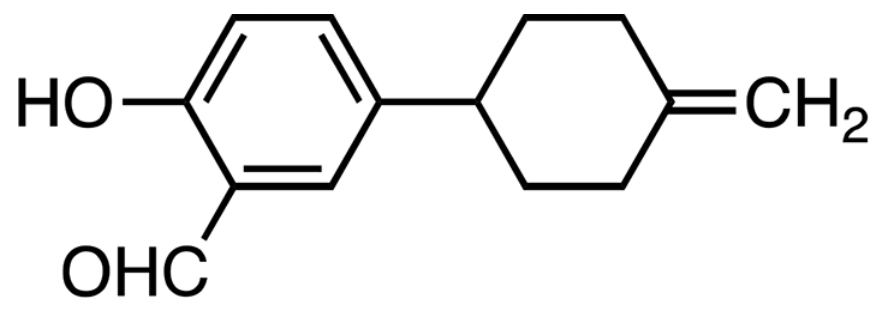

(9)

To a solution of $7(0.100 \mathrm{~g}, 0.531 \mathrm{mmol})$ in dry $\mathrm{CH}_{3} \mathrm{CN}(20 \mathrm{~mL})$ were sequentially added $\mathrm{MgCl}_{2}(0.076 \mathrm{~g}, 0.797)$ and triethylamine $(0.28 \mathrm{~mL}, 2.0 \mathrm{mmol})$, followed by paraformaldehyde $(0.108 \mathrm{~g}, 3.59 \mathrm{mmol})$. The mixture was heated at reflux for $6 \mathrm{~h}$. The mixture was cooled to room temperature and quenched with $10 \% \mathrm{HCl}(10 \mathrm{~mL})$ and extracted several times with ethyl acetate. The combined extracts were washed with brine, dried $\left(\mathrm{Na}_{2} \mathrm{SO}_{4}\right)$, and concentrated. Purification of the residue by column chromatography $\left(\mathrm{SiO}_{2}\right.$, hexanes-diethyl ether $\left.=4: 1\right)$ gave $9(0.046 \mathrm{~g}, 40 \%)$ as a colorless oil. ${ }^{1 H} \mathrm{H}$ NMR $\left(400 \mathrm{MHz}, \mathrm{CD}_{3} \mathrm{OD}\right) \delta 9.96(\mathrm{~s}, 1 \mathrm{H}), 7.50(\mathrm{~s}, 1 \mathrm{H}), 7.39(\mathrm{~d}, J=8.5 \mathrm{~Hz}, 1 \mathrm{H}), 6.85(\mathrm{~d}, J=8.5 \mathrm{~Hz}, 1 \mathrm{H}), 4.65$ $(\mathrm{t}, J=1.7 \mathrm{~Hz}, 2 \mathrm{H}), 2.68(\mathrm{tt}, J=12.0,3.4 \mathrm{~Hz}, 1 \mathrm{H}), 2.44-2.34(\mathrm{~m}, 2 \mathrm{H}), 2.24-2.13(\mathrm{~m}, 2 \mathrm{H}), 1.97-1.89(\mathrm{~m}, 2 \mathrm{H}), 1.49(\mathrm{qd}, J=$ 13.0, $4.0 \mathrm{~Hz}, 2 \mathrm{H}) .{ }^{13} \mathrm{C}$ NMR $\left(100 \mathrm{MHz}, \mathrm{CD}_{3} \mathrm{OD}\right) \delta$ 197.5, 161.0, 149.8, 139.9, 137.0, 131.6, 122.5, 118.2, 108.2, 44.3, 36.9, $36.2 \mathrm{ppm}$. HRMS $\mathrm{m} / \mathrm{z} 231.1027$ [calcd for $\mathrm{C}_{14} \mathrm{H}_{15} \mathrm{O}_{3}{ }^{-}\left(\mathrm{M}-\mathrm{H}^{+}\right)$231.1027].

\section{2-Hydroxy-5-(4-methylenecyclohexyl)benzaldehyde Oxime (10)}

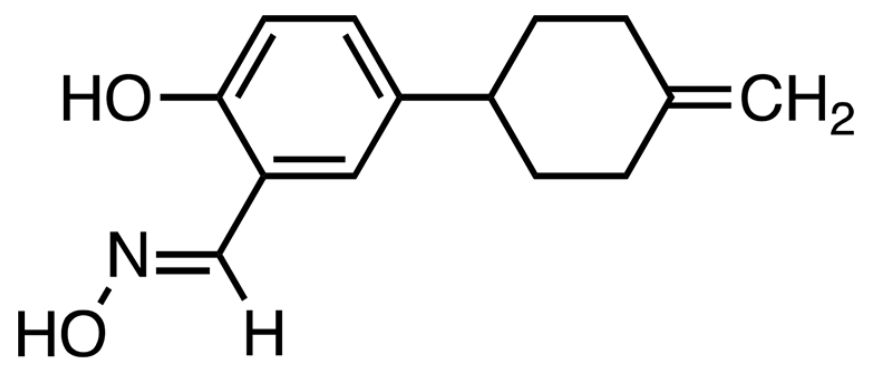

\section{(10)}

To a solution of $9(0.050 \mathrm{~g}, 0.232 \mathrm{mmol})$ in pure ethanol $(10 \mathrm{~mL})$ were added sodium bicarbonate $(0.024 \mathrm{~g}, 0.278$ $\mathrm{mmol}$ ) and hydroxylamine hydrochloride $(0.025 \mathrm{~g}, 0.348 \mathrm{mmol})$. The reaction was heated at $80{ }^{\circ} \mathrm{C}$ for $5 \mathrm{~h}$, and the mixture was extracted several times with ethyl acetate. The combined organic extracts were dried $\left(\mathrm{MgSO}_{4}\right)$ and concentrated. Purification of the residue by column chromatography $\left(\mathrm{SiO}_{2}\right.$, hexanes-ethyl acetate $\left.=13: 7\right)$ gave $10(0.037 \mathrm{~g}, 69 \%)$ as a colorless solid; $\mathrm{mp} 120-125^{\circ} \mathrm{C} .{ }^{1} \mathrm{H} \mathrm{NMR}\left(400 \mathrm{MHz}, \mathrm{CD}_{3} \mathrm{OD}\right) \delta 8.20(\mathrm{~s}, 1 \mathrm{H}), 7.09-7.06(\mathrm{~m}$, $1 \mathrm{H}), 7.05(\mathrm{~d}, J=2.4 \mathrm{~Hz}, 1.8 \mathrm{H}), 6.99(\mathrm{~d}, J=7.9 \mathrm{~Hz}, 0.2 \mathrm{H}), 6.78(\mathrm{~d}, J=8.1 \mathrm{~Hz}, 0.8 \mathrm{H}), 6.68(\mathrm{~d}, J=8.6 \mathrm{~Hz}, 0.2 \mathrm{H}), 4.63(\mathrm{t}, J=$ $1.6 \mathrm{~Hz}, 2 \mathrm{H}), 2.60(\mathrm{tt}, J=12.2,3.3 \mathrm{~Hz}, 1 \mathrm{H}), 2.42-2.33(\mathrm{~m}, 2 \mathrm{H}), 2.22-2.10(\mathrm{~m}, 2 \mathrm{H}), 1.94-1.85(\mathrm{~m}, 2 \mathrm{H}), 1.46(\mathrm{qd}, J=12.5$, $4.0 \mathrm{~Hz}, 2 \mathrm{H}) .{ }^{13} \mathrm{C}$ NMR $\left(100 \mathrm{MHz}, \mathrm{CD}_{3} \mathrm{OD}\right) \delta$ 156.6, 152.4, 150.1, 139.4, 130.2, 129.2, 128.7, 118.5, 117.2, 116.2, 108.0, 107.7, 44.5, 37.3, 37.1, 36.4, 36.3 ppm. HRMS $\mathrm{m} / \mathrm{z} 230.1187$ [calcd for $\mathrm{C}_{14} \mathrm{H}_{16} \mathrm{NO}_{3^{-}}\left(\mathrm{M}-\mathrm{H}^{+}\right)$230.1186].

\section{4-(4-((t-Butyldimethylsilyl)oxy)phenyl)-1-(hydroxymethyl)cyclohexan-1-ol (11)}

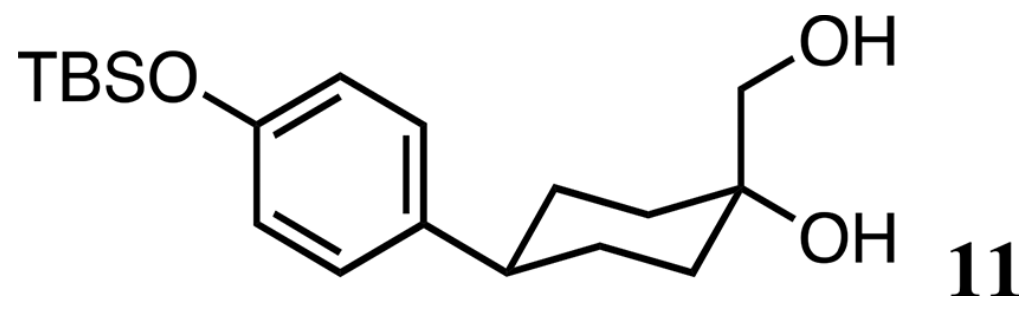

To a solution of $6(0.280 \mathrm{~g}, 0.926 \mathrm{mmol})$ and $N$-methylmorpholine- $N$-oxide $(0.13 \mathrm{~mL}, 1.3 \mathrm{mmol})$ in acetone $(6 \mathrm{~mL})$ and distilled water $(0.3 \mathrm{~mL})$ was added a solution of $\mathrm{OsO}_{4}$ in tert-butanol $(2.5 \%, 90 \mu \mathrm{L})$. The mixture was stirred overnight, and saturated aqueous $\mathrm{NaHSO}_{3}(10 \mathrm{~mL})$ was added to quench the reaction. The mixture was diluted with ether and washed several times with water. The organic layer was dried $\left(\mathrm{MgSO}_{4}\right)$, concentrated, and the residue purified by column chromatography $\left(\mathrm{SiO}_{2}\right.$, hexanes-ethyl acetate $\left.=1: 4\right)$ to give $\mathbf{1 1}(0.267 \mathrm{~g}, 86 \%)$ as a colorless solid; mp 80-86 
${ }^{\circ} \mathrm{C} .{ }^{1 \mathrm{H}} \mathrm{NMR}\left(400 \mathrm{MHz}, \mathrm{CDCl}_{3}\right) \delta 7.04$ and $6.75\left(\mathrm{AA}^{\prime} \mathrm{XX}\right.$ ', $\left.\mathrm{J}_{\mathrm{AX}}=8.5 \mathrm{~Hz}, 4 \mathrm{H}\right), 3.69(\mathrm{~s}, 2 \mathrm{H}), 2.52(\mathrm{tt}, J=11.4,3.6 \mathrm{~Hz}, 1 \mathrm{H}), 2.04-$ $1.72\left(\mathrm{~m}, 4 \mathrm{H}\right.$, solvent peak overlap), 1.61-1.37 (m, 4H), $0.97(\mathrm{~s}, 9 \mathrm{H}), 0.18(\mathrm{~s}, 6 \mathrm{H}) .{ }^{13} \mathrm{C} \mathrm{NMR}\left(100 \mathrm{MHz}, \mathrm{CDCl}_{3}\right) \delta 154.0$, $138.9,127.7,120.0,72.4,66.2,42.8,35.4,31.3,25.9,18.4,-4.2 \mathrm{ppm}$.

\section{4-(4-Hydroxy-4-(hydroxymethyl)cyclohexyl)phenol (12)}

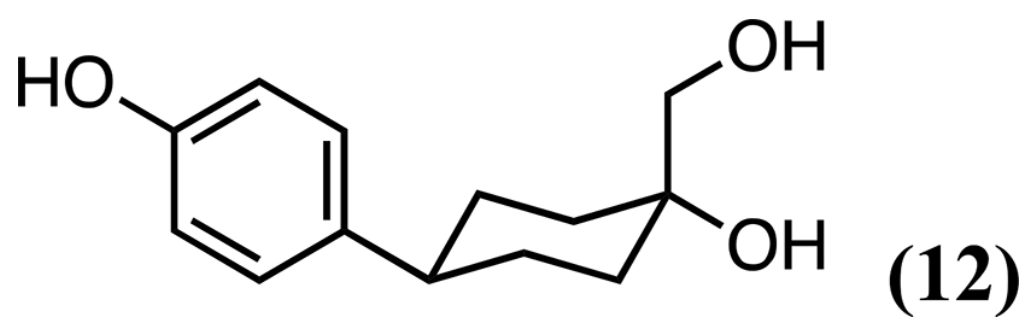

To a solution of $11(0.230 \mathrm{~g}, 0.683 \mathrm{mmol})$ in anhydrous THF $(10 \mathrm{~mL})$ was added a solution of TBAF (1 M in THF, $2.8 \mathrm{~mL}$, $2.8 \mathrm{mmol}$ ). The mixture was heated at reflux for $6 \mathrm{~h}$ and cooled to room temperature. The solution was partitioned between ethyl acetate and water. The combined organic layers were washed with brine, dried $\left(\mathrm{Na}_{2} \mathrm{SO}_{4}\right)$, and concentrated. Purification of the residue by column chromatography $\left(\mathrm{SiO}_{2}\right.$, ethyl acetate-methanol $\left.=9: 1\right)$ gave $12(0.118 \mathrm{~g}, 78 \%)$ as a colorless solid; $m p 182-188^{\circ} \mathrm{C} .{ }^{1} \mathrm{H}$ NMR $\left(400 \mathrm{MHz}, \mathrm{CD}_{3} \mathrm{OD}\right) \delta 7.02$ and $6.68\left(\mathrm{AA}^{\prime} \mathrm{XX}^{\prime}, \mathrm{J}_{\mathrm{AX}}=\right.$ $8.5 \mathrm{~Hz}, 4 \mathrm{H}), 3.62(\mathrm{~s}, 2 \mathrm{H}), 2.53-2.42(\mathrm{~m}, 1 \mathrm{H}), 1.99-1.89(\mathrm{~m}, 2 \mathrm{H}), 1.85-1.68(\mathrm{~m}, 2 \mathrm{H}), 1.58-1.43(\mathrm{~m}, 4 \mathrm{H}) .{ }^{13} \mathrm{C}$ NMR $(100$ $\left.\mathrm{MHz}, \mathrm{CD}_{3} \mathrm{OD}\right) \delta 156.6,138.9,128.8,116.2,73.1,66.6,44.3,36.0,32.6 \mathrm{ppm}$. Anal. Calcd for $\mathrm{C}_{13} \mathrm{H}_{18} \mathrm{O}_{3}: \mathrm{C}, 70.24 ; \mathrm{H}, 8.16$. Found: $\mathrm{C}, 70.18 ; \mathrm{H}, 7.78$.

\section{4-(4-t-Butyldimethylsilyloxyphenyl)cyclohexyl)methanol (13/14)}

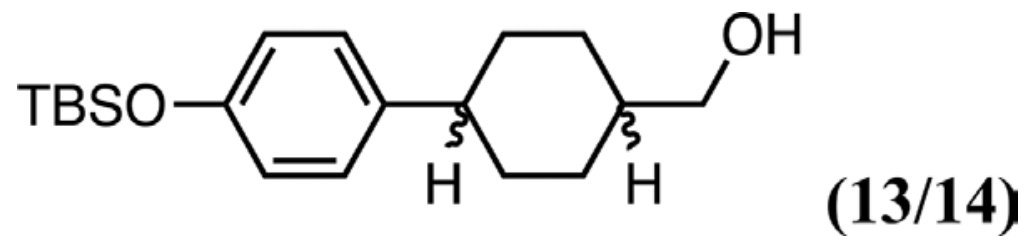

To a solution of $6(0.821 \mathrm{~g}, 2.71 \mathrm{mmol})$ in THF $(24 \mathrm{~mL})$ at $0{ }^{\circ} \mathrm{C}$ under $\mathrm{N}_{2}$ was added a solution of borane-THF complex (1 M in THF, $5.4 \mathrm{~mL}, 5.4 \mathrm{mmol}$ ). The reaction mixture was slowly warmed to room temperature and stirred for $20 \mathrm{~h}$. The mixture was then cooled to $0{ }^{\circ} \mathrm{C}$, followed by sequential addition of ethanol $(50 \mathrm{~mL})$, hydrogen peroxide solution ( $30 \%$ in water, $4.0 \mathrm{~mL}$ ), and $1 \mathrm{~N} \mathrm{NaOH}$ solution $(20 \mathrm{~mL})$. The mixture was warmed to room temperature and stirred for $90 \mathrm{~min}$. The reaction mixture was quenched with saturated sodium bicarbonate solution $(10 \mathrm{~mL})$, diluted with water $(20 \mathrm{~mL})$, and extracted with several times with ethyl acetate. The combined organic extracts were washed with brine, dried $\left(\mathrm{Na}_{2} \mathrm{SO}_{4}\right)$, and concentrated. Purification of the residue by column chromatography $\left(\mathrm{SiO}_{2}\right.$, hexanes-ethyl acetate $=7: 3$ ) gave a colorless oil $(0.572 \mathrm{~g}, 66 \%)$. This was determined to be a 2:1 mixture of cis-13 and trans-14 by ${ }^{1} \mathrm{H}$ NMR integration of the signals for the $\mathrm{CH}_{2} \mathrm{OH}$ groups at $\delta 3.69$ and $3.50 \mathrm{ppm}$, respectively. ${ }^{1} \mathrm{H} \mathrm{NMR}\left(400 \mathrm{MHz}, \mathrm{CDCl}_{3}\right) \delta 7.06$ and $6.76\left(\mathrm{AA}^{\prime} X X^{\prime}, J_{A X}=8.5 \mathrm{~Hz}, 4 \mathrm{H}\right), 3.69(\mathrm{~d}, J=7.4 \mathrm{~Hz}, 1.3 \mathrm{H}), 3.50(\mathrm{~d}, J=6.5 \mathrm{~Hz}, 0.7 \mathrm{H}), 2.59-2.51(\mathrm{~m}, 0.5 \mathrm{H}), 2.42(\mathrm{tt}, J=$ 12.1, 3.8 Hz, 0.5H), 1.96-1.84 (m, 2H), 1.80-1.37 (m, 7H), $0.98(\mathrm{~s}, 9 \mathrm{H}), 0.19(\mathrm{~s}, 6 \mathrm{H}) \mathrm{ppm} .{ }^{13} \mathrm{C} \mathrm{NMR}\left(100 \mathrm{MHz}, \mathrm{CDCl}_{3}\right) \delta$ $153.7,140.4,140.0,127.8,119.9,68.9,64.6,43.8,42.6,40.3,36.2,34.1,30.0,29.4,27.0,25.9,18.4,-4.2$ ppm. Use of 9-BBN instead of $\mathrm{BH}_{3}-\mathrm{THF}$ gave a 2:3 mixture of cis-13:trans-14 (74\%).

\section{4-(4-(Hydroxymethyl)cyclohexyl)phenol (15/16)}

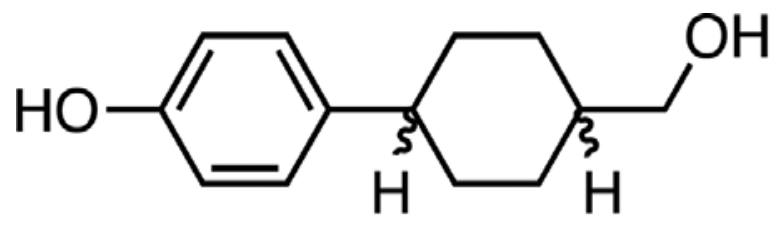

\section{$(15 / 16)$}

To a solution of $13 / 14(0.594 \mathrm{~g}, 1.85 \mathrm{mmol}, 2: 1$ mixture $c: t)$ in dry THF $(10 \mathrm{~mL})$ was added a solution of TBAF (1 M in THF, $7.5 \mathrm{~mL}, 7.5 \mathrm{mmol})$. The reaction mixture was heated to reflux at $70{ }^{\circ} \mathrm{C}$ overnight and cooled to room temperature. The solution was partitioned between ethyl acetate and water. The organic layer was washed with brine, dried $\left(\mathrm{Na}_{2} \mathrm{SO}_{4}\right)$, and concentrated. The residue was purified by column chromatography $\left(\mathrm{SiO}_{2}\right.$, hexanes-ethyl 
acetate $=3: 2)$ to give a colorless solid $(0.280 \mathrm{~g}, 73 \%)$. This was determined to be a 2:1 mixture of cis-13 and trans14stereoisomers by ${ }^{1} \mathrm{H}$ NMR integration of the signals for the $\mathrm{CH}_{2} \mathrm{OH}$ groups at $\delta 3.60$ and $3.39 \mathrm{ppm}$, respectively; mp 118-122 ${ }^{\circ} \mathrm{C} .{ }^{1 \mathrm{H}} \mathrm{NMR}\left(400 \mathrm{MHz}, \mathrm{CD}_{3} \mathrm{OD}\right) \delta 7.04-6.98(\mathrm{~m}, 2 \mathrm{H}), 6.70-6.65(\mathrm{~m}, 2 \mathrm{H}), 3.60(\mathrm{~d}, J=7.6 \mathrm{~Hz}, 1.5 \mathrm{H}), 3.39(\mathrm{~d}, J=$ $6.6 \mathrm{~Hz}, 0.5 \mathrm{H}), 2.54-2.44(\mathrm{~m}, 1 \mathrm{H}), 2.37(\mathrm{tt}, J=12.1,3.4 \mathrm{~Hz}, 1 \mathrm{H}), 1.93-1.70(\mathrm{~m}, 3 \mathrm{H}), 1.61(\mathrm{~d}, J=6.3 \mathrm{~Hz}, 4 \mathrm{H}), 1.46-1.37$ $(\mathrm{m}, 1 \mathrm{H}), 1.14-1.02(\mathrm{~m}, 1 \mathrm{H}) \mathrm{ppm} .{ }^{13} \mathrm{C}$ NMR $\left(100 \mathrm{MHz}, \mathrm{CD}_{3} \mathrm{OD}\right) \delta$ 156.2, 139.6, 128.7, 116.0, 68.0, 64.4, 45.2, 44.0, 41.4, $37.0,35.4,31.2,30.5,28.0 \mathrm{ppm}$.

\section{1-(4-Hydroxyphenyl)-2-oxabicyclo[2.2.2]octane (17) and trans-(Hydroxymethyl)cyclohexyl)phenol (16)}

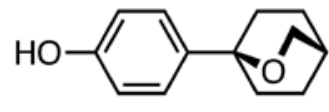<smiles>OCC1CCC(c2ccc(O)cc2)CC1</smiles>

(16)

To a solution of $15 / 16\left(0.080 \mathrm{~g}, 0.388 \mathrm{mmol}, 2: 3\right.$ mixture of cis-15:trans-16) in anhydrous $\mathrm{CH}_{2} \mathrm{Cl}_{2}(20 \mathrm{~mL})$ at $-10{ }^{\circ} \mathrm{C}$ was slowly added, over a period of $30 \mathrm{~min}$, a suspension of 2,3-dichloro-5,6-dicyano-1,4-benzoquinone (0.044 g, 0.194 $\mathrm{mmol})$ in $\mathrm{CH}_{2} \mathrm{Cl}_{2}(4 \mathrm{~mL})$. The green solution was stirred at $0{ }^{\circ} \mathrm{C}$ for $2 \mathrm{~h}$ and gradually warmed to room temperature and stirred for another $3 \mathrm{~h}$. The mixture was quenched by slow addition of saturated sodium bicarbonate solution at $0{ }^{\circ} \mathrm{C}$. After $10 \mathrm{~min}$, the layers were separated and the aqueous layer was extracted several times with $\mathrm{CH}_{2} \mathrm{Cl}_{2}$. The combined organic extracts were washed with brine, dried $\left(\mathrm{Na}_{2} \mathrm{SO}_{4}\right)$, and concentrated. The residue was purified by column chromatography $\left(\mathrm{SiO}_{2}\right.$, hexanes-ethyl acetate $\left.=3: 2\right)$ to give $17(0.029 \mathrm{~g}, 37 \%)$ followed by $16(0.038 \mathrm{~g}, 47 \%)$, both as colorless solids. Purity of $\mathbf{1 6}$ was established by ${ }^{1} \mathrm{H}$ NMR (Supporting Information, Figure S9).

17: $\mathrm{mp} 120-124^{\circ} \mathrm{C} .{ }^{1} \mathrm{H}$ NMR $\left(400 \mathrm{MHz}, \mathrm{CD}_{3} \mathrm{OD}\right) \delta 7.18$ and $6.64\left(\mathrm{AA}^{\prime} \mathrm{XX}^{\prime}, J_{\mathrm{AX}}=7.9 \mathrm{~Hz}, 4 \mathrm{H}\right), 4.04(\mathrm{~s}, 2 \mathrm{H}), 2.01(\mathrm{t}, J=7.8$ $\mathrm{Hz}, 4 \mathrm{H}), 1.94-1.73(\mathrm{~m}, 5 \mathrm{H}) .{ }^{13} \mathrm{C} N M R\left(100 \mathrm{MHz}, \mathrm{CD}_{3} \mathrm{OD}\right) \delta 157.3,139.0,127.2,115.8,73.2,71.5,34.7,27.5,26.1 \mathrm{ppm}$. Anal. Calcd for $\mathrm{C}_{13} \mathrm{H}_{16} \mathrm{O}_{2}: \mathrm{C}, 76.44 ; \mathrm{H}, 7.89$. Found: $\mathrm{C}, 76.39 ; \mathrm{H}, 7.97$.

16: $\mathrm{mp} 115-120^{\circ} \mathrm{C} .{ }^{1} \mathrm{H}$ NMR (400 MHz, $\left.\mathrm{CD}_{3} \mathrm{OD}\right) \delta 7.00$ and $6.68\left(\mathrm{AA}^{\prime} X X^{\prime}, \mathrm{J}_{\mathrm{AX}}=8.7 \mathrm{~Hz}, 4 \mathrm{H}\right), 3.39(\mathrm{~d}, J=6.7 \mathrm{~Hz}, 2 \mathrm{H}), 2.36$ $(\mathrm{tt}, J=12.1,3.0 \mathrm{~Hz}, 1 \mathrm{H}), 1.87$ (broad t, $J=15.4,4 \mathrm{H}), 1.55-1.36(\mathrm{~m}, 3 \mathrm{H}), 1.14-1.02(\mathrm{~m}, 2 \mathrm{H}) .{ }^{13} \mathrm{C} \mathrm{NMR}\left(100 \mathrm{MHz}, \mathrm{CD}_{3} \mathrm{OD}\right)$ $\delta$ 156.5, 140.0, 128.7, 116.1, 68.9, 45.3, 41.5, 35.5, 31.3 ppm. Anal. Calcd for $\mathrm{C}_{13} \mathrm{H}_{18} \mathrm{O}_{2}: \mathrm{C}, 75.69 ; \mathrm{H}, 8.79$. Found: $\mathrm{C}$, 75.66; H, 9.09.

\section{4'-(Hydroxymethyl)-2',3',4',5'-tetrahydro-[1,1'-biphenyl]-4-ol (( \pm )-19)}

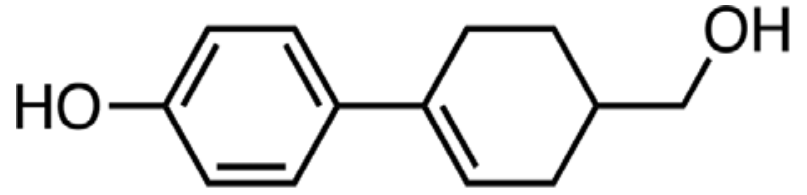

$$
( \pm)-19
$$

To a solution of $17(0.103 \mathrm{~g}, 0.504 \mathrm{mmol})$ in dry $\mathrm{CH}_{3} \mathrm{CN}(25 \mathrm{~mL})$ was added $\mathrm{MgCl}_{2}(0.072 \mathrm{~g}, 0.756 \mathrm{mmol})$ followed by triethylamine $(0.26 \mathrm{~mL}, 1.89 \mathrm{mmol})$. The mixture was heated at reflux for $8 \mathrm{~h}$ then cooled and quenched with $10 \% \mathrm{HCl}$ $(15 \mathrm{~mL})$. The mixture was extracted several times with ethyl acetate, and the combined extracts washed with brine, dried $\left(\mathrm{Na}_{2} \mathrm{SO}_{4}\right)$, and concentrated. Purification of the residue by column chromatography $\left(\mathrm{SiO}_{2}\right.$, hexanes-ethyl acetate = 13:7) gave $19\left(0.080 \mathrm{~g}, 78 \%\right.$ ) as a colorless solid; mp $177-184^{\circ} \mathrm{C} .{ }^{1} \mathrm{H} \mathrm{NMR}\left(400 \mathrm{MHz}, \mathrm{CD}_{3} \mathrm{OD}\right) \delta 7.20$ and 6.69 $\left(A^{\prime} X X^{\prime}, J_{A X}=8.6 \mathrm{~Hz}, 4 \mathrm{H}\right), 5.97-5.92(\mathrm{~m}, 1 \mathrm{H}), 3.48(\mathrm{dd}, J=6.4,2.6 \mathrm{~Hz}, 2 \mathrm{H}), 2.49-2.23(\mathrm{~m}, 3 \mathrm{H}), 2.01-1.71(\mathrm{~m}, 4 \mathrm{H}), 1.43-$ $1.31(\mathrm{~m}, 1 \mathrm{H}) .{ }^{13} \mathrm{C}$ NMR $\left(100 \mathrm{MHz}, \mathrm{CD}_{3} \mathrm{OD}\right) \delta 157.5,137.7,135.3,127.2,122.1,116.0,68.0,37.5,30.1,28.2,27.2 \mathrm{ppm}$. HRMS $m / z 203.1078$ [calcd for $\mathrm{C}_{13} \mathrm{H}_{15} \mathrm{O}_{2}-\left(\mathrm{M}-\mathrm{H}^{+}\right)$203.1077].

\section{4-(4-((t-Butyldiphenylsilyl)oxy)phenyl)cyclohexan-1-one (21)}
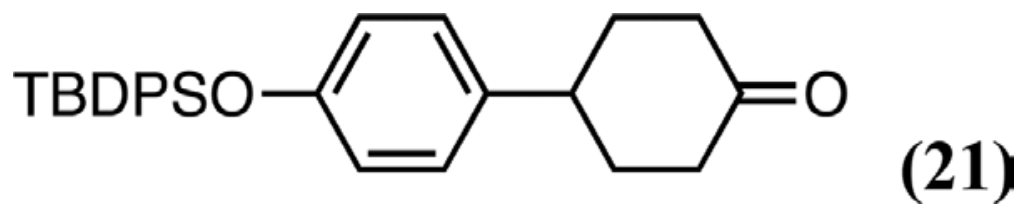

To a solution of $1(0.815 \mathrm{~g}, 4.28 \mathrm{mmol})$ in dry $\mathrm{CH}_{2} \mathrm{Cl}_{2}(30 \mathrm{~mL})$ at $0{ }^{\circ} \mathrm{C}$ was added imidazole $(0.583 \mathrm{~g} 8.57 \mathrm{mmol})$ followed by dropwise addition of a solution of $t$-butyldiphenylsilyl chloride $(1.60 \mathrm{~mL}, 5.57 \mathrm{mmol})$ in $\mathrm{CH}_{2} \mathrm{Cl}_{2}(9 \mathrm{~mL})$. The reaction mixture was slowly warmed to room temperature and stirred for $12 \mathrm{~h}$. The mixture was diluted with water and 
extracted several times with $\mathrm{CH}_{2} \mathrm{Cl}_{2}$. The combined extracts were washed with brine, dried $\left(\mathrm{Na}_{2} \mathrm{SO}_{4}\right)$, and concentrated. The residue was purified by column chromatography $\left(\mathrm{SiO}_{2}\right.$, hexanes-ethyl acetate $\left.=4: 1\right)$ to give $21(1.70 \mathrm{~g}, 93 \%)$ as a colorless solid; $\mathrm{mp} 83-84^{\circ} \mathrm{C} .{ }^{1 \mathrm{H}} \mathrm{NMR}\left(400 \mathrm{MHz}, \mathrm{CDCl}_{3}\right) \delta 7.74-7.70(\mathrm{~m}, 4 \mathrm{H}), 7.45-7.34(\mathrm{~m}$, $6 \mathrm{H}), 6.96$ and $6.71\left(\mathrm{AA}^{\prime} \mathrm{BB}^{\prime}, J_{\mathrm{AB}}=8.6 \mathrm{~Hz}, 4 \mathrm{H}\right), 2.90(\mathrm{tt}, \mathrm{J}=12.1,3.3 \mathrm{~Hz}, 1 \mathrm{H}), 2.49-2.42(\mathrm{~m}, 4 \mathrm{H}), 2.19-2.10(\mathrm{~m}, 2 \mathrm{H}), 1.91-$ $1.77(\mathrm{~m}, 2 \mathrm{H}), 1.09(\mathrm{~s}, 9 \mathrm{H}) .{ }^{13} \mathrm{C} \mathrm{NMR}\left(100 \mathrm{MHz}, \mathrm{CDCl}_{3}\right) \delta 211.6,154.3,137.3,135.7,133.2,130.1,127.9,127.5,119.8$, $42.1,41.6,34.3,26.7,19.7 \mathrm{ppm}$.

Methyl 2-(4-(4-t-Butyldiphenylsilyloxyphenyl)cyclohexylidene)acetate (( \pm )-22)
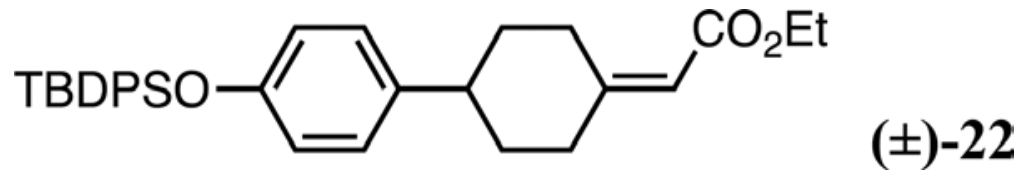

To a solution of trimethyl phosphonoacetate $(0.160 \mathrm{~mL}, 0.980 \mathrm{mmol})$ in dry THF $(5 \mathrm{~mL})$ at $0{ }^{\circ} \mathrm{C}$ was added NaH $(40 \mathrm{mg}$, $55 \%$ in mineral oil, $0.980 \mathrm{mmol})$. After stirring for $45 \mathrm{~min}$, a solution of $\mathbf{2 1}(0.350 \mathrm{~g}, 0.816 \mathrm{mmol})$ in dry THF (5 mL) was added and the mixture was warmed to room temperature and stirred for $8 \mathrm{~h}$. The mixture was diluted with water and extracted several times with ether. The combined extracts were dried $\left(\mathrm{MgSO}_{4}\right)$ and concentrated. The residue was purified by column chromatography $\left(\mathrm{SiO}_{2}\right.$, hexanes-ethyl acetate $\left.=9: 1\right)$ to give $\mathbf{2 2}(0.376 \mathrm{~g}, 95 \%)$ as colorless gum. ${ }^{1} \mathrm{H}$ $\operatorname{NMR}\left(400 \mathrm{MHz}, \mathrm{CDCl}_{3}\right) \delta 7.74-7.68(\mathrm{~m}, 4 \mathrm{H}), 7.44-7.32(\mathrm{~m}, 6 \mathrm{H}), 6.91$ and $6.69\left(\mathrm{AA}^{\prime} \mathrm{XX}^{\prime}, \mathrm{J}_{\mathrm{AX}}=8.6 \mathrm{~Hz}, 4 \mathrm{H}\right), 5.65(\mathrm{~s}, 1 \mathrm{H})$, 3.96-3.88 (m, 1H), $3.69(\mathrm{~s}, 3 \mathrm{H}), 2.66(\mathrm{tt}, J=12.1,3.4 \mathrm{~Hz}, 1 \mathrm{H}), 2.38-2.24(\mathrm{~m}, 2 \mathrm{H}), 2.04-1.93(\mathrm{~m}, 3 \mathrm{H}), 1.59-1.46(\mathrm{~m}, 2 \mathrm{H})$, 1.08 (s, 9H). ${ }^{13} \mathrm{C} \mathrm{NMR}\left(100 \mathrm{MHz}, \mathrm{CDCl}_{3}\right) \delta 167.4,162.7,154.0,138.6,135.7,133.3,130.0,127.9,127.5,119.6,113.3$, 51.10, 43.3, 37.9, 35.9, 35.1, 29.7, 26.7, $19.7 \mathrm{ppm}$.

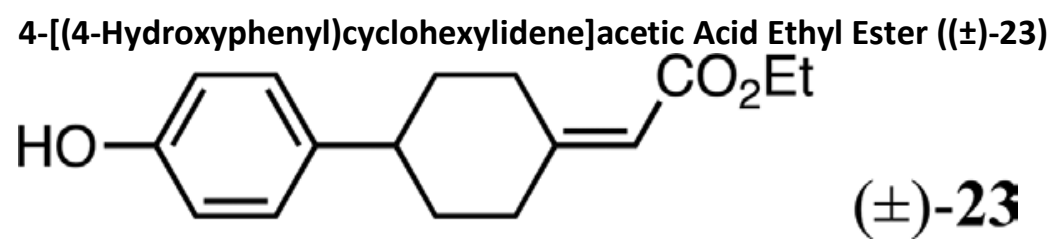

To a stirred solution of $22(60 \mathrm{mg}, 0.12 \mathrm{mmol})$ in dry THF $(1 \mathrm{~mL})$ was added a solution of tetrabutylammonium fluoride $(0.247 \mathrm{~mL}, 1.0 \mathrm{M}$ in THF, $0.247 \mathrm{mmol})$. The solution was stirred at room temperature after $1 \mathrm{~h}$, and then the mixture was diluted with water and extracted with ethyl acetate. The combined extracts were washed with brine, dried, and concentrated. The residue was purified by preparative $\mathrm{TLC}\left(\mathrm{SiO}_{2}\right.$, hexanes-ethyl acetate $\left.=9: 1\right)$ to give $23(20 \mathrm{mg}, 64 \%)$ as a colorless solid; mp 92-94 ${ }^{\circ} \mathrm{C} .{ }^{1} \mathrm{H}$ NMR $\left(\mathrm{CDCl}_{3}, 300 \mathrm{MHz}\right) \delta 7.08$ and $6.77\left(\mathrm{AA}^{\prime} \mathrm{XX}^{\prime}, \mathrm{J}_{\mathrm{AB}}=8.4 \mathrm{~Hz}, 4 \mathrm{H}\right), 5.68(\mathrm{~s}, 1 \mathrm{H}), 4.58$ $(\mathrm{s}, 1 \mathrm{H}), 4.17(\mathrm{q}, J=7.1 \mathrm{~Hz}, 2 \mathrm{H}), 4.00-3.90(\mathrm{~m}, 1 \mathrm{H}), 2.80-2.68(\mathrm{~m}, 1 \mathrm{H}), 2.45-1.97(\mathrm{~m}, 6 \mathrm{H}), 1.30(\mathrm{t}, J=7.3 \mathrm{~Hz}, 3 \mathrm{H}) .{ }^{13} \mathrm{C}$ NMR $\left(\mathrm{CDCl}_{3}, 75 \mathrm{MHz}\right) \delta 167.0,162.2,154.0,138.6,128.1,115.4,113.9,59.8,43.4,37.9,36.0,35.2,29.7,14.5 \mathrm{ppm}$. HRMS $m / z 259.1339$ [calcd for $\mathrm{C}_{16} \mathrm{H}_{19} \mathrm{O}_{3}^{-}\left(\mathrm{M}-\mathrm{H}^{+}\right)$259.1340].

4-(4'-Hydroxyphenyl)(2-hydroxyethylidene)cyclohexane (( \pm$)-25)$

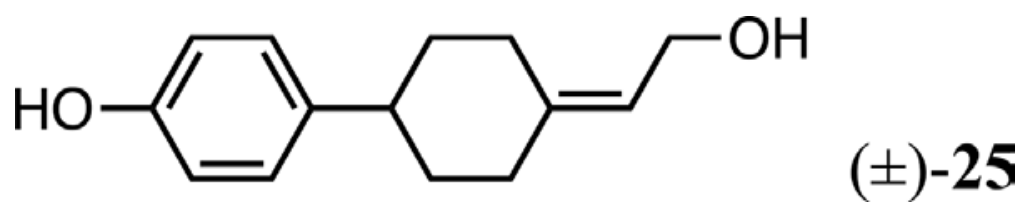

To a solution of $22(275 \mathrm{mg}, 0.551 \mathrm{mmol})$ in dry $\mathrm{CH}_{2} \mathrm{Cl}_{2}(2 \mathrm{~mL})$ under $\mathrm{N}_{2}$ at $-40{ }^{\circ} \mathrm{C}$ was added a solution of diisobutylaluminum hydride (1.0 M in $\mathrm{CH}_{2} \mathrm{Cl}_{2}, 1.41 \mathrm{~mL}, 1.41 \mathrm{mmol}$ ). After $90 \mathrm{~min}$, saturated aqueous potassium sodium tartrate was added and reaction mixture warmed to room temperature. After $2 \mathrm{~h}$, the layers were separated and the aqueous layer was extracted several times with $\mathrm{CH}_{2} \mathrm{Cl}_{2}$. The combined organic layers were dried, filtered through a pad of Celite, and concentrated to give 4-(4'-t-butyldiphenylsilyloxyphenyl)(2-

hydroxyethylidene)cyclohexane ( $254 \mathrm{mg}$, quantitative) as a colorless gum. This compound was used without further purification. To a solution of the crude allylic alcohol $(235 \mathrm{mg}, 0.514 \mathrm{mmol})$ in dry THF $(1 \mathrm{~mL})$ under nitrogen was added a solution of tetrabutylammonium fluoride in (1.0 M in THF, $1.03 \mathrm{~mL}, 1.03 \mathrm{mmol})$. The solution was stirred for $3 \mathrm{~h}$ and then diluted with water and the resultant mixture extracted several times with ethyl acetate. The combined extracts were washed with brine, dried, and concentrated. The residue was purified by column chromatography $\left(\mathrm{SiO}_{2}\right.$, 
hexanes-ethyl acetate $=4: 1)$ to give $25(90 \mathrm{mg}, 80 \%)$ as a colorless solid; $\mathrm{mp} 165-166^{\circ} \mathrm{C}$. ${ }^{1} \mathrm{H}$ NMR (acetone- $d_{6}, 300$ $\mathrm{MHz}) \delta 8.10(\mathrm{~s}, 1 \mathrm{H}), 7.04$ and $6.74\left(\mathrm{AA}^{\prime} X X^{\prime}, J_{\mathrm{AX}}=8.4 \mathrm{~Hz}, 4 \mathrm{H}\right), 5.36(\mathrm{t}, J=6.6 \mathrm{~Hz}, 1 \mathrm{H}), 4.17-4.02(\mathrm{~m}, 2 \mathrm{H}), 2.78-2.70(\mathrm{~m}$, $1 \mathrm{H}), 2.64(\mathrm{tt}, J=3.3,12.0 \mathrm{~Hz}, 1 \mathrm{H}), 2.35-2.10(\mathrm{~m}, 2 \mathrm{H}), 1.98-1.80(\mathrm{~m}, 4 \mathrm{H}), 1.54-1.37(\mathrm{~m}, 2 \mathrm{H}) .{ }^{13} \mathrm{C}$ NMR (acetone- $d_{6}, 75$ $\mathrm{MHz}) \delta 156.5,141.1,138.6,128.5,123.6,116.0,58.5,44.6,37.5,37.0,36.2,29.2$. Anal. Calcd for $\mathrm{C}_{14} \mathrm{H}_{18} \mathrm{O}_{2}: \mathrm{C}, 77.03 ; \mathrm{H}$ 8.31. Found: $C, 77.20 ; H, 8.28$.

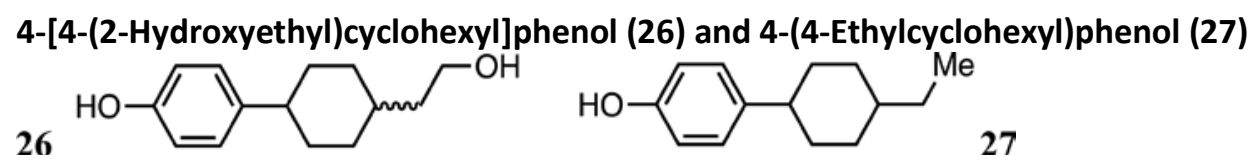

A solution of 25 ( $50 \mathrm{mg}, 0.23 \mathrm{mmol})$ in methanol $\left(15 \mathrm{~mL}\right.$ ) with a small pinch of $20 \% \mathrm{Pd} / \mathrm{C}$ was stirred under $\mathrm{H}_{2}(30 \mathrm{psi})$ for $12 \mathrm{~h}$. The reaction mixture was filtered through a pad of Celite and concentrated, and the residue was purified by preparative $\mathrm{TLC}\left(\mathrm{SiO}_{2}\right.$, hexanes-ethyl acetate $\left.=13: 7\right)$ to give $\mathbf{2 7}(28 \mathrm{mg}, 60 \%)$, followed by $26(7 \mathrm{mg}, 14 \%)$ both as colorless solids.

27: $\mathrm{mp} 120-125^{\circ} \mathrm{C} .{ }^{1} \mathrm{H}$ NMR (acetone- $\left.d_{6}, 300 \mathrm{MHz}\right) \delta 8.02(\mathrm{~s}, 1 \mathrm{H}), 7.08-7.01(\mathrm{~m}, 2 \mathrm{H}), 6.77-6.71(\mathrm{~m}, 2 \mathrm{H}), 3.65-3.56 \mathrm{and}$ 3.43-3.37 (m, 3H total), 2.52-2.33 (m, 1H), 1.91-1.00 (m, 11H). ${ }^{13} \mathrm{C}$ NMR (acetone- $\left.d_{6}, 75 \mathrm{MHz}\right) \delta 156.4,139.5,128.6$, $115.9,61.1,60.4,44.6,41.4,35.5,34.8,34.5,31.1,30.3 \mathrm{ppm}$. HRMS $\mathrm{m} / \mathrm{z} 219.139$ [calcd for $\mathrm{C}_{14} \mathrm{H}_{19} \mathrm{O}_{2}{ }^{-}\left(\mathrm{M}-\mathrm{H}^{+}\right)$ 219.1390].

26: $\mathrm{mp} 80-81^{\circ} \mathrm{C} .{ }^{1} \mathrm{H} N M R\left(\mathrm{CDCl}_{3}, 300 \mathrm{MHz}\right) \delta 7.08$ and $6.76\left(\mathrm{AA}^{\prime} X X^{\prime}, \mathrm{J}_{\mathrm{AX}}=8.1 \mathrm{~Hz}, 4 \mathrm{H}\right), 4.55(\mathrm{~s}, 1 \mathrm{H}), 2.54-2.35(\mathrm{~m}, 1 \mathrm{H})$, $1.92-1.82(\mathrm{~m}, 2 \mathrm{H}), 1.70-1.50(\mathrm{~m}, 3 \mathrm{H}), 1.45-1.00(\mathrm{~m}, 6 \mathrm{H}), 0.91(\mathrm{t}, J=7.2 \mathrm{~Hz}, 3 \mathrm{H}) \mathrm{ppm}$.

\section{TR-FRET Assay}

LanthaScreen TR-FRET ER Alpha and Beta Competitive Binding Assay kits from Thermo Fisher Scientific were used to perform the TR-FRET assays. These included a terbium-labeled anti-GST antibody, a fluorescent small-molecule ER $\alpha$ or $\beta$ ligand as a "tracer", and a human ER $\alpha$ or $\beta$ ligand-binding domain (LBD) that is tagged with glutathione-Stransferase (GST) in a homogeneous mix-and-read assay format.

The TR-FRET assay employs a Tb-anti-GST antibody that binds to a GST tag, and a fluorescently labeled estrogen (tracer) binds in the active site pocket. The TR-FRET signal obtained decreases when competitor compounds displace the fluorescently labeled tracer. Assays were performed according to kit instructions. Briefly, 1:5 dilution series of compounds were made with DMSO then diluted in assay buffer such that the highest concentration tested in the assay was $50 \mu \mathrm{M}$ and DMSO was $1 \%$. Assays were set up in 384-well white, small volume plates (Corning 4512). The assay was incubated for $1 \mathrm{~h}$ in the dark at room temperature, after which plates were spun at $1000 \mathrm{rpm}$ in a tabletop centrifuge equipped with a swing-out rotor (Eppendorf 5810, rotor A-4-64). TR-FRET signal was read on a SpectraMax M5 (Molecular Devices) setup according to Thermo Fisher Scientific machine settings (excitation of $332 \mathrm{~nm}$, emissions 518 and $488 \mathrm{~nm}$ with a $420 \mathrm{~nm}$ cutoff, $50 \mu$ s integration delay, $400 \mu$ s integration time, and 100 flashes per read). The TR-FRET ratio was calculated using the SoftmaxPro software by dividing the emission at $518 \mathrm{~nm}$ (fluorescein) by the emission at $488 \mathrm{~nm}$ (Terbium). Data were normalized to $E_{2}$, which had an $\mathrm{EC}_{50}$ of $0.25 \pm 0.06 \mathrm{nM}$ in this assay. Data analysis was done using Prism (GraphPad Software, Inc., La Jolla, CA), with fits typically constrained to go to zero at high concentrations of competing ligand. Standard deviations are for the nonlinear least-squares fit of the data. When replicate assays and fits were done, curves are shown (Figure 2 and Supporting Information, Figure S1) and fitted $\mathrm{EC}_{50} \mathrm{~S}$ summarized in Table 1) for curves that gave median $\mathrm{EC}_{50}$ values.

\section{Nuclear Hormone Receptor Specificity Assay}

Selectivity measurements were performed using the SelectScreen cell-based nuclear receptor profiling service from ThermoFisher (Figure 3). Nuclear receptors (NRs) to be screened in the specificity assay were selected based on two main criteria: (a) sequence and structural similarity to estrogen receptor and (b) availability of the assay. When choosing between possible isoforms, we chose those that were more likely to be involved in CNS function. This is a FRET-based assay that uses GeneBLAzer technology. It detects ligand binding to and activation of a nuclear hormone receptor of interest (ligand binding domain; LBD) that is fused to a GAL4 DNA binding domain (DBD), which upon activation induces expression of $\beta$-lactamase. The assay has a $Z^{\prime} \geq 0.5$ in agonist mode. Compound stocks were in DMSO and diluted for assay concentrations of $0.25,2.5$, and $25 \mu \mathrm{M}$. Data for estrogen receptors were normalized to 
$\mathrm{E}_{2}$, which had an $\mathrm{EC}_{50}$ of $0.107 \mathrm{nM}$ for $\mathrm{ER} \alpha$ and $0.579 \mathrm{nM}$ for $\mathrm{ER} \beta$. Data for other receptors were normalized to an appropriate control, which are listed with $\mathrm{EC}_{50}$ values in Supporting Information, Table S1. Repeat assays for ER $\alpha$ and $E R \beta$ agonist assays in a 10-point curve were also completed (Figure $3 b$ ). Data again were normalized to $E_{2}$, which had $\mathrm{EC}_{50}$ values of 0.151 and $0.568 \mathrm{nM}$ for $\mathrm{ER} \alpha$ and $\mathrm{ER} \beta$, respectively.

\section{Coactivator Assay}

The LanthaScreen TR-FRET assay from ThermoFisher was used (Figure 4a), similar to the assay described above (Figure 3), except this LanthaScreen assay has a fluorescently labeled coactivator peptide present. The assay measures recruitment of the labeled coactivator peptide to the ER $\alpha$ or ER $\beta$ LBD, induced by the binding of the ER agonist being assayed. The coactivator peptide is PGC1a, derived from the PPAR $\gamma$ coactivator protein $1 \mathrm{a}$, and containing an LXXLL motif (sequence: EAEEPSLLKKLLLAPANTQ). Data were normalized to $E_{2}$, which had an $\mathrm{EC}_{50}$ of 2.58 and $2.79 \mathrm{nM}$ for $E R \alpha$ and $E R \beta$, respectively.

\section{Cell-Based Assays}

$E R \alpha$ and ER $\beta$ cell-based assays for both agonist and antagonist activity measurements were performed using kits provided by Indigo Biosciences (Figure 5). Assays relied on a luciferase reporter gene that was downstream from either an $E R \alpha$ - or $E R \beta$-responsive promoter and activated by an added agonist or had agonist activity blocked by an added antagonist. ER-induced luciferase expression was quantified using chemiluminescence, measured using a SpectraMax M5 plate reader. Stock solutions of ligands were prepared in DMSO and diluted to final concentrations (typically low $\mathrm{nM}$ to $\mu \mathrm{M}$ ), using the Compound Screening Medium provided in the kit, such that the DMSO concentration in the assay was kept below the assay limit of $0.4 \%$. Vehicle controls were included in both agonist and antagonist assays. Assays were conducted according to kit instructions. Briefly, cells directly from the freezer were diluted in Cell Recovery Media (provided) and warmed for $5 \mathrm{~min}$ at $37^{\circ} \mathrm{C}$. The cell suspension was divided in half. Estradiol, $E_{2}$, was added to one-half of the cells for antagonist assays, while the remaining cells without $E_{2}$ were used for the agonist assay. Cells were plated, and compounds to be screened were added. Plates were incubated in an incubator at $37^{\circ} \mathrm{C}$ with $5 \% \mathrm{CO}_{2}$ for $22 \mathrm{~h}$. Assays were typically performed in duplicate. Luminescence was measured using a SpectraMax M5 plate reader, after removal of media and addition of the Luciferin Detection Reagent. Data were normalized to $E_{2}$, which had agonist activity $\mathrm{EC}_{50}$ of $0.31 \pm 0.03$ and $0.022 \pm 0.005 \mathrm{nM}$ for $E R \alpha$ and $E R \beta$, respectively. Data were fitted to the equation below using GraphPad Prism:

$$
y=\frac{\text { bottom }+(\text { top }- \text { bottom })}{\left(1+10^{\left(\text {loglC } \text { se }_{s}-x\right) \text { Hill Slope }}\right)}
$$

As described for the TR-FRET assay fitting, $\mathrm{EC}_{50}$ values and standard deviations are from the nonlinear least-squares fit of the data, and when replicate assays and fits were done, median values were reported in Table 1.

\section{In Vitro Druggability Assays: CYP450 Binding, hERG, and Nephelometry}

The P450-Glo Screening System from Promega Corporation (Madison, WI) was used to measure CYP450 (cytochrome P450) inhibition, as described in the kit instructions. Assays were run in 96-well white plates (Corning 3912), and luminescence was measured on a SpectraMax M5 instrument (Figure 6). The luminescence signal is proportional to the amount of luciferin product formed by the CYP reaction. Compounds were prepared in DMSO, then an eight-step 1:2 dilution series was made in DMSO. This was diluted in water such that the DMSO in the assay did not exceed $0.25 \%$ and the highest final concentration of compound was $62.5 \mu \mathrm{M}$. After adding the relevant cytochrome P450 enzyme, the plate was incubated at $37^{\circ} \mathrm{C}$ for $10 \mathrm{~min}$ to allow components to come to temperature. Next, the NADPH regeneration system was added to activate the reaction on a luminogenic P450-Glo substrate and incubated at $37^{\circ} \mathrm{C}$ for 10-30 min according to kit instructions for each CYP enzyme. The enzyme reaction was stopped by the addition of Luciferin Detection Reagent, and luminescence of the plate was read in a Spectramax M5 (Molecular Devices) after a 20 min incubation at room temperature. Data were normalized to positive controls ( $\alpha$-naphthoflavone for CYP1A2, sulfaphenazole for CYP2C9, quinidine for CYP2D6, and ketoconazole for CYP3A4). Data analysis was with Prism software, as described above. 
Nephelometry was performed to determine the relative propensity of compounds to aggregate in solution (Supporting Information, Figure S3a) based on the light scattering properties of the molecular aggregates. Compound aggregation in solution is important to measure in screening campaigns, as aggregation is a common source of artifactual activity and it provides a measure of compound solubility. Compounds were tested for aggregation in clear 96-well plates (Greiner BioOne). Progesterone was used as a positive control for compound aggregation. Data were collected using a BMG NEPHELOStar Plus, equipped with a $635 \mathrm{~nm}$ laser.

hERG assays were performed using the SelectScreen service from ThermoFisher (Supporting Information, Figure S3b). The assay is a fluorescence polarization assay that measures displacement of a fluorescently tagged predictor tracer, as described.(47)

\section{MTT Assays}

Human breast cancer cells (MCF-7) were provided by Dr. Manish Patankar (Department of Obstetrics and Gynecology, University of Wisconsin-Madison). Cells were cultured in Eagle's Minimum Essential Media (EMEM) supplemented with $10 \%$ fetal bovine serum and $0.01 \mathrm{mg} / \mathrm{mL}$ human recombinant insulin in $5 \% \mathrm{CO}_{2}$ at $37^{\circ} \mathrm{C}$. A seeding density of 7000 cells per well was chosen and applied to a 96-well plate. After $24 \mathrm{~h}$, treatments of ISP358-2, DPN, or estradiol in media containing $0.1 \%$ dimethyl sulfoxide (DMSO) were applied to the cells at varying concentrations $(10,1,0.1,0.01$, and $0.001 \mu \mathrm{M})$. Negative, positive, and untreated control cells received 100\% DMSO, $0.01 \mu \mathrm{M}$ estradiol in EMEM or EMEM with $0.1 \%$ DMSO content, respectively. Treated cells were incubated for $24 \mathrm{~h}$, after which an 3-(4,5dimethylthiazol-2-yl)-2,5-diphenyltetrazolium bromide (MTT) assay was performed by adding $20 \% \mathrm{MTT}$ in EMEM solution to each well and incubating for $4 \mathrm{~h}$. Formazan crystal metabolites were dissolved using $100 \%$ DMSO, and absorbance was read at OD $570 \mathrm{~nm}$ as well as a reference of $650 \mathrm{~nm}$ using a VMax kinetic microplate reader (Molecular Devices, CA) running Softmax Pro version 6.1. Absorbances were converted to cell number using a standard growth curve. Two-sample equal variance $t$-tests were conducted using Microsoft Excel to determine if cell proliferation was significantly different from untreated controls or cells treated with $0.1 \mu \mathrm{M} \mathrm{E}_{2}$.

\section{Docking}

Three dimensional (3D) conformations were prepared for all ligands before docking (Figure 7). AutoDock Tools (ADT) version 1.5.6 was used prepare the ligand files for subsequent AutoDock calculations and assign Gasteiger charges. The ER $\alpha$ receptor for agonist ( $\mathrm{pdb}$ 1ere)(36) and antagonist (pdb 1err)(48) conformations were prepared for docking calculations, and the ER $\beta$ receptor for agonist (pdb 2jj3)(49) and antagonist ( $p \mathrm{db} 1 / 2 \mathrm{j})(50)$ conformations were also prepared for docking calculations. ADT was used to add hydrogen atoms and partial charges to each atom of the protein. The grid box was centered on the cocrystallized ligand, drawn to a box to incorporate active site amino acids (Arg394, Glu353, and His524 for ER $\alpha$ and Arg346, Glu305, and His475 for ERß), and the estradiol ligand was removed.(51) AutoDock Vina(52) was used for docking calculations, with default parameters, except that an energy range of 4 and exhaustiveness of 8 were used.(47,53-56) As a control experiment, 17 $\beta$-estradiol was docked into the structure of $E R \alpha$ (pdb 1ere), after removing $17 \beta$-estradiol, and found to adopt the same binding mode as for the originally bound $17 \beta$-estradiol (Supporting Information, Figure S4).

\section{Assessment of Memory Consolidation}

\section{Subjects}

C57BL/6 female mice (8-10 weeks of age) were purchased from Taconic Biosciences. Mice were singly housed in a 12 $\mathrm{h}$ light/dark cycle room, with food and water ad libitum. All procedures with live mice were performed between 9:00 am and $6: 00 \mathrm{pm}$ in a room with a light intensity of dimmer than $100 \mathrm{~lx}$. All procedures were approved by the University of Wisconsin-Milwaukee Institutional Animal Care and Use Committee and observed policies of the National Institutes of Health Guide for the Care and Use of Laboratory Animals.

\section{General Experimental Design}

A series of three experiments were conducted in mice that were bilaterally ovariectomized to remove the primary source of circulating estrogens. In each experiment, a negative control (dimethyl sulfoxide, DMSO), positive control (2,3-bis(4-hydroxyphenyl)-propionitrile, DPN), and multiple doses of ISP358-2 were administered to separate groups of mice via one of three routes of administration: direct bilateral dorsal hippocampal infusion, intraperitoneal injection, or oral gavage. All drugs were administered acutely immediately after training in object recognition and 
object locations tasks designed to test hippocampal-dependent object recognition and spatial memory consolidation, respectively, as described below (Figure 8).

\section{Surgery}

Four days after arrival in the laboratory, mice were bilaterally ovariectomized as described previously. $(34,57,58)$ Mice slated to receive dorsal hippocampal infusion of ISP358-2 were also implanted with guide cannulae into the dorsal hippocampus (DH) as described previously.(30-32)Mice were anesthetized with isoflurane gas (2\% isoflurane in $100 \%$ oxygen) and placed in a stereotaxic apparatus (Kopf Instruments). Immediately after ovariectomy, mice were implanted with two guide cannulae (22 gauge; C232G, Plastics One) aimed at the dorsal hippocampus ( $-1.7 \mathrm{~mm}$ AP, $\pm 1.5 \mathrm{~mm} \mathrm{ML},-2.3 \mathrm{~mm}$ DV). Dummy cannulae (C232DC, Plastics One) were placed inside the guide cannulae to conserve patency of the guide cannulae. Dental cement (Darby Dental) was applied to anchor the guide cannulae to the skull and also served to close the wound. Mice were allowed to recover for 6 days before behavioral testing.

\section{Drugs and Infusions}

Dorsal hippocampal (DH) infusions or intraperitoneal (IP) injections were conducted immediately post-training as described previously. $(34,57,58)$ During infusions, mice were gently restrained and drugs delivered using an infusion cannula (C3131, 28 gauge, extending $0.8 \mathrm{~mm}$ beyond the $1.5 \mathrm{~mm}$ guide). The infusion cannula was connected to a 10 $\mu \mathrm{L}$ Hamilton syringe using PE20 polyethylene tubing. The infusion was controlled by a microinfusion pump (KDS Legato 180, KD Scientific) at a rate of $0.5 \mu \mathrm{L} / \mathrm{min}$. Each infusion was followed by a 1 min waiting period to prevent diffusion back up the cannula track and allow the drug to diffuse through the tissue. The negative control ("vehicle") was $1 \%$ DMSO in $0.9 \%$ saline. As a positive control, the ER $\beta$ agonist 2,3-bis(4-hydroxyphenyl)-propionitrile (DPN, Tocris Bioscience) was dissolved in 1\% DMSO in saline and infused at a dose of $10 \mathrm{pg} / \mathrm{hemisphere.(30)} \mathrm{DPN} \mathrm{has} \mathrm{a} \mathrm{70-}$ fold higher affinity for $E R \beta$ than $E R \alpha,(59)$ and bilateral infusion of $10 \mathrm{pg} /$ hemisphere into the dorsal hippocampus previously enhanced memory consolidation in the object recognition and object placement tasks in young adult ovariectomized mice.(34) ISP358-2 was dissolved in 1\% DMSO to a concentration of $2 \mathrm{ng} / \mu \mathrm{L}$ and then diluted to administer doses of $1 \mathrm{ng} /$ hemisphere, $100 \mathrm{pg} / \mathrm{hemisphere,} \mathrm{and} 10 \mathrm{pg} /$ hemisphere.

For intraperitoneal injections, ISP358-2 was dissolved in 10\% DMSO in physiological saline and injected at doses of 0.5 or $5 \mathrm{mg} / \mathrm{kg}$ in a volume of $10 \mathrm{~mL} / \mathrm{kg}$. DPN was dissolved in $10 \%$ DMSO in saline and injected at a dose of $0.05 \mathrm{mg} / \mathrm{kg}$ in volume of $10 \mathrm{~mL} / \mathrm{kg}$. This dose previously enhanced object recognition memory consolidation in young adult ovariectomized mice.(31) Vehicle controls received $10 \mathrm{~mL} / \mathrm{kg}$ of $10 \%$ DMSO in saline. For oral gavage, all drugs were administered in a volume of $10 \mathrm{~mL} / \mathrm{kg}$ at the same doses as intraperitoneal injections; $0.5 \mathrm{or} 5 \mathrm{mg} / \mathrm{kg}$ ISP358-2 and $0.05 \mathrm{mg} / \mathrm{kg}$ DPN. Vehicle controls received 10\% DMSO in saline. In the procedure, a bulb tipped gastric gavage needle ( $24 \mathrm{GA}, 25 \mathrm{~mm}$ ) was used to deliver the drugs directly to the stomach.

\section{Memory Testing}

Object recognition and object placement were performed as described previously. $(34,57,58)$ Object recognition and object placement evaluated object recognition memory and spatial memory, respectively, and required intact dorsal hippocampal function. $(39,60-62)$ Mice were first handled $(30 \mathrm{~s} / \mathrm{d})$ for 3 days to acclimate them to the experimenters. On the second day of handling, a small Lego was placed in the home cage to habituate the mice to objects. This Lego was removed from the cage just before training. After 3 days of handling, mice were habituated to an empty white arena (width, $60 \mathrm{~cm}$; length, $60 \mathrm{~cm}$; height, $47 \mathrm{~cm}$ ) by allowing them to explore freely for 5 min each day for 2 days. On the training day, mice were habituated for $2 \mathrm{~min}$ in the arena and then removed to their home cage. Two identical objects were then placed near the northwest and northeast corners of the arena. Mice were returned to the arena and allowed to explore until they accumulated a total of $30 \mathrm{~s}$ of exploring the objects (or until a total of $20 \mathrm{~min}$ had elapsed). Immediately after this training, mice were removed from the arena, infused, and then returned to their home cage. Object placement memory was tested $24 \mathrm{~h}$ after training by moving one of the training objects to the southeast or southwest corner of the box. Because mice inherently prefer novelty, mice that remember the location of the training objects spend more time with the moved object than the unmoved object. Mice performing at chance (15 s) spend an equal amount of time with each object and demonstrate no memory consolidation. Thus, consolidation of memory for the training objects is demonstrated if mice spend significantly more time than chance with the moved object. Object recognition training was conducted 2 weeks after object placement. The object recognition task used the same apparatus and general procedure as object placement, but instead of changing the object location, one familiar object was replaced with a new object during testing. Object recognition testing occurred 
$48 \mathrm{~h}$ after training. As with object placement, mice accumulated $30 \mathrm{~s}$ of exploring the novel and familiar objects. Because mice are inherently drawn to novelty, more time than chance spent exploring the novel object indicated memory for the familiar training object. To maintain novelty, different objects were used in the object placement and object recognition tasks. Because vehicle-infused female mice do not remember the location of the training objects $24 \mathrm{~h}$ after training,(34) a $24 \mathrm{~h}$ delay was used to test the memory-enhancing effects of drugs in object placement. Similarly, because vehicle-infused female mice do not remember the familiar object $48 \mathrm{~h}$ after training,(34) a $48 \mathrm{~h}$ delay was used to test the memory-enhancing effects of drugs in object recognition. For both tasks, the time spent exploring each object and elapsed time to accumulate $30 \mathrm{~s}$ of exploration were recorded using ANYmaze tracking software (Stoelting).

\section{Behavioral Data Analysis}

One-sample $t$-tests and one-way analyses of variance (ANOVAs) were conducted using GraphPad Prism 6 (La Jolla, CA). One-sample $t$-tests were used to determine whether mice spent significantly more time than chance (15 s) investigating the novel or moved object, indicating whether each group of mice successfully formed a memory of the identity and location of the training objects. To determine the extent to which DPN or ISP358-2 treatment influenced memory consolidation relative to vehicle, between-group comparisons were conducted for each behavioral task using one-way ANOVAs, followed by Fisher's LSD post hoc tests. Significance was determined at $p>0.05$.

\section{Assessment of Potential Peripheral Pathology}

To assess possible toxicity of ISP358-2 treatment to peripheral organs, ovariectomized mice received a single intraperitoneal injection of vehicle or ISP358-2, and liver, kidney, and heart tissues were collected $24 \mathrm{~h}$ later. Similar to behavioral testing, ISP358-2 was injected at doses of 0.5 or $5 \mathrm{mg} / \mathrm{kg}$ in a volume of $10 \mathrm{~mL} / \mathrm{kg}$ and DPN was injected at a dose of $0.05 \mathrm{mg} / \mathrm{kg}$ in a volume of $10 \mathrm{~mL} / \mathrm{kg}$. Vehicle controls received $10 \mathrm{~mL} / \mathrm{kg}$ of $10 \%$ DMSO in saline (Supporting Information, Figure S6a). Tissues were fixed in 10\% formalin buffered solution for $24 \mathrm{~h}$. Twenty specimens were processed and analyzed. Each specimen contained three pieces of tissue. The tissues from each animal was transferred to a labeled cassette and processed on an automated tissue processor following standard procedures. The tissues were then embedded in paraffin wax. No specific orientation of the tissue was performed. Four-micrometer sections were cut from each paraffin block and placed onto a slide. The slides were then stained using hematoxylin and eosin (H\&E) on an automated stainer (Supporting Information, Figure S6b). The slides were then examined by a pathologist (ACM) who is board certified in anatomical pathology by the American Board of Pathology. All specimens contained three tissue samples corresponding to liver, kidney, and heart. In some instances, portions of adjacent tissues were also present. For example, several specimens had a gall bladder. One specimen had a portion of spleen. Each organ was examined for specific pathological changes. Three major categories of change were examined: (1) Structural changes to the organs. For liver, the central vein, portal triads, and hepatocytes were examined. For kidneys, the glomeruli and tubules were examined. For heart, the myocytes and coronary vessels were examined. (2) Evidence of inflammation was evaluated including hepatitis, glomerulonephritis, interstitial nephritis, and myocarditis. (3) Evidence of ischemic changes was examined. See Table 1 for a summary of the findings.

\section{Supporting Information}

The Supporting Information is available free of charge on the ACS Publications website at DOI: 10.1021/acs.jmedchem.7b01601.

- Control compounds and $\mathrm{EC}_{50}$ values for the nuclear hormone specificity assay; $\mathrm{ER} \beta$ binding assay; cell-based assays comparing ISP358-2 to known compounds; assessment of in vitro druggability parameters; Control docking into $E R \alpha$; in vivo correlation of behavioral effect and ERß levels; tissue pathology analysis for ISP358-2; bloodwork panel for tissue pathology analysis for ISP358-2; MTT assay for proliferation of MCF-7 cells; Purity analysis of ISP358-2 (16); calculated BBB penetration (PDF)

- Molecular formula strings for compounds (CSV)

- jm7b01601_si_001.csv (0.57 kB) PDF jm7b01601_si_002.pdf (1.15 MB) 
A-C Estrogens as Potent and Selective Estrogen Receptor-Beta Agonists (SERBAs) to Enhance Memory Consolidation under Low-Estrogen Conditions

Showing 1/2: jm7b01601_si_001.csv

\begin{tabular}{|c|c|c|}
\hline & $A$ & B \\
\hline 1 & compd \# & SMILES \\
\hline 2 & 1 & $O C 1=C C=C(C 2 C C C(C C 2)=O) C=C 1$ \\
\hline 3 & 2 & $\mathrm{OC} 1=\mathrm{CC}=\mathrm{C}([\mathrm{C} @ @ \mathrm{H}] 2 \mathrm{CC}[\mathrm{C} @ @ \mathrm{H}](\mathrm{O}) \mathrm{CC} 2) \mathrm{C}=\mathrm{C} 1$ \\
\hline 4 & 3 & OC1=CC=C([C@@H]2CC[C@@] $(O)(C) C C 2) C=C 1$ \\
\hline 5 & 4 & $O C 1=C C=C(C 2 C C / C(C C 2)=N / O) C=C 1$ \\
\hline 6 & 7 & $O C 1=C C=C(C 2 C C C(C C 2)=C) C=C 1$ \\
\hline 7 & 8 & $\mathrm{OC} 1=\mathrm{CC}=\mathrm{C}(\mathrm{C} 2 \mathrm{CCC}(\mathrm{C}) \mathrm{CC} 2) \mathrm{C}=\mathrm{C} 1$ \\
\hline 8 & 9 & $O C 1=C C=C(C 2 C C C(C C 2)=C) C=C 1 C=0$ \\
\hline 9 & 10 & $\mathrm{OC} 1=\mathrm{CC}=\mathrm{C}(\mathrm{C} 2 \mathrm{CCC}(\mathrm{CC} 2)=\mathrm{C}) \mathrm{C}=\mathrm{C} 1 / \mathrm{C}([\mathrm{H}])=\mathrm{N} / \mathrm{O}$ \\
\hline 10 & 12 & $\mathrm{OC} 1=\mathrm{CC}=\mathrm{C}([\mathrm{C} @ @ \mathrm{H}] 2 \mathrm{CC}[\mathrm{C} @ @](\mathrm{CO})(\mathrm{O}) \mathrm{CC} 2) \mathrm{C}=\mathrm{C} 1$ \\
\hline 11 & 15 & OC1=CC=C([C@@@ $] 2 C C[C @ H](C O) C C 2) C=C 1$ \\
\hline 12 & 16 & OC1=CC=C([C@@ @H]2CC[C@@H](CO)CC2)C=C1 \\
\hline 13 & 17 & OC1=CC=C([C@@@]2(OC3)CC[C@H]3CC2)C=C1 \\
\hline 14 & 19 & $\mathrm{OC} 1=\mathrm{CC}=\mathrm{C}(\mathrm{C} 2=\mathrm{CCC}(\mathrm{CO}) \mathrm{CC} 2) \mathrm{C}=\mathrm{C} 1$ \\
\hline 15 & 22 & $\mathrm{OC} 1=\mathrm{CC}=\mathrm{C}(\mathrm{C} 2 \mathrm{CC} / \mathrm{C}(\mathrm{CC} 2)=\mathrm{C} / \mathrm{C}(\mathrm{OCC})=\mathrm{O}) \mathrm{C}=\mathrm{C} 1$ \\
\hline 16 & 24 & $O C 1=C C=C(C 2 C C / C(C C 2)=C / C O) C=C 1$ \\
\hline 17 & 25 & $\mathrm{OC} 1=\mathrm{CC}=\mathrm{C}(\mathrm{C} 2 \mathrm{CCC}(\mathrm{CCO}) \mathrm{CC} 2) \mathrm{C}=\mathrm{C}$ \\
\hline
\end{tabular}

\section{Author Contributions}

K.M.F., W.A.D., and D.S.M. contributed equally. The manuscript was written through contributions of all authors. All authors have given approval to the final version of the manuscript.

The authors declare no competing financial interest.

\section{Acknowledgments}

We thank Dr. Sergey Lindeman (Staff Crystallographer, Marquette University) for obtaining the crystal structure of ISP358-2. This work was supported by grant R15GM118304 from the National Institute of General Medical Sciences. K.M.F. also acknowledges the support of the University of Wisconsin-Milwaukee College of Letters \& Science and a UWM Research Foundation Catalyst Grant.

\begin{tabular}{|l|l|}
\hline $\begin{array}{l}\text { Abbreviations } \\
\text { Used }\end{array}$ & \\
\hline AD & Alzheimer's disease \\
\hline ANOVA & analyses of variance \\
\hline AR & androgen receptor \\
\hline DBD & DNA binding domain \\
\hline DMSO & dimethyl sulfoxide \\
\hline DH & dorsal hippocampus \\
\hline DPN & diarylpropionitrile \\
\hline$E_{2}$ & $17 \beta$ estradiol \\
\hline ER & estrogen receptor \\
\hline
\end{tabular}




\begin{tabular}{|l|l|}
\hline GR & glucocorticoid receptor \\
\hline IP & intraperitoneal \\
\hline LBD & ligand binding domain \\
\hline $\mathrm{mp}$ & melting point \\
\hline $\mathrm{MR}$ & $\begin{array}{l}\text { mineralocorticoid receptor } \\
\text { bromide }\end{array}$ \\
\hline $\mathrm{MTT}$ & nuclear hormone receptor \\
\hline $\mathrm{NR}$ & object placement \\
\hline OP & object recognition \\
\hline OR & proliferator-activated receptor-delta \\
\hline PPARS & progesterone receptor \\
\hline PR & thyroid hormone receptor-beta \\
\hline TRB & time-resolved fluorescence resonance energy transfer \\
\hline TR-FRET & vitamin D receptor \\
\hline VDR & \\
\hline
\end{tabular}

\section{References}

1. Manas, E. S.; Unwalla, R. J.; Xu, Z. B.; Malamas, M. S.; Miller, C. P.; Harris, H. A.; Hsiao, C.; Akopian, T.;Hum, W. T.; Malakian, K.; Wolfrom, S.; Bapat, A.; Bhat, R. A.; Stahl, M. L.; Somers, W. S.; Alvarez, J. C.Structure-based design of estrogen receptor-beta selective ligands. J. Am. Chem. Soc. 2004, 126, 15106-15119, DOI: 10.1021/ja047633o

2. Malamas, M. S.; Manas, E. S.; McDevitt, R. E.; Gunawan, I.; Xu, Z. B.; Collini, M. D.; Miller, C. P.; Dinh, T.;Henderson, R. A.; Keith, J. C., Jr.; Harris, H. A. Design and synthesis of aryl diphenolic azoles as potent and selective estrogen receptor-beta ligands. J. Med. Chem. 2004, 47, 5021- 5040, DOI: 10.1021/jm049719y

3. Liu, F.; Day, M.; Muniz, L. C.; Bitran, D.; Arias, R.; Revilla-Sanchez, R.; Grauer, S.; Zhang, G.; Kelley, C.;Pulito, V.; Sung, A.; Mervis, R. F.; Navarra, R.; Hirst, W. D.; Reinhart, P. H.; Marquis, K. L.; Moss, S. J.;Pangalos, M. N.; Brandon, N. J. Activation of estrogen receptor-beta regulates hippocampal synaptic plasticity and improves memory. Nat. Neurosci. 2008, 11, 334-343, DOI: 10.1038/nn2057

4. ClinicalTrials.gov Home Page; NIH U.S. National Library of Medicine: Bethesda, MD. 2017; https://www.clinicaltrials.gov (accessed Oct 8, 2017).

5. Sarvari, M.; Kallo, I.; Hrabovszky, E.; Solymosi, N.; Rodolosse, A.; Liposits, Z. Long-term estrogen receptor beta agonist treatment modifies the hippocampal transcriptome in middle-aged ovariectomized rats. Front. Cell. Neurosci. 2016, 10, 149, DOI: 10.3389/fncel.2016.00149

6. Frick, K. M.; Kim, J.; Tuscher, J. J.; Fortress, A. M. Sex steroid hormones matter for learning and memory: estrogenic regulation of hippocampal function in male and female rodents. Learn Mem 2015, 22, 472-493,DOI: 10.1101/Im.037267.114

7. Tian, Z.; Fan, J.; Zhao, Y.; Bi, S.; Si, L.; Liu, Q. Estrogen receptor beta treats Alzheimer's disease. Neural Regener. Res. 2013, 8, 420-426, DOI: 10.3969/j.issn.1673-5374.2013.05.005

8. Chen, L. H.; Fan, Y. H.; Kao, P. Y.; Ho, D. T.; Ha, J. C.; Chu, L. W.; Song, Y. Q. Genetic polymorphisms in estrogen metabolic pathway associated with risks of alzheimer's disease: evidence from a Southern Chinese Population. J. Am. Geriatr. Soc. 2017, 65, 332-339, DOI: 10.1111/jgs.14537

9. Farrer, L. A.; Cupples, L. A.; Haines, J. L.; Hyman, B.; Kukull, W. A.; Mayeux, R.; Myers, R. H.;Pericak-Vance, M. A.; Risch, N.; van Duijn, C. M. Effects of age, sex, and ethnicity on the association between apolipoprotein $E$ genotype and Alzheimer disease. A meta-analysis. APOE and Alzheimer Disease Meta Analysis Consortium. JAMA 1997, 278, 1349-1356, DOI: 10.1001/jama.1997.03550160069041

10. Altmann, A.; Tian, L.; Henderson, V. W.; Greicius, M. D. Alzheimer's disease Neuroimaging Initiative, I. Sex modifies the APOE-related risk of developing Alzheimer disease. Ann. Neurol. 2014, 75, 563-573, DOI: 10.1002/ana.24135 
11. Bretsky, P. M.; Buckwalter, J. G.; Seeman, T. E.; Miller, C. A.; Poirier, J.; Schellenberg, G. D.; Finch, C. E.;Henderson, V. W. Evidence for an interaction between apolipoprotein E genotype, gender, and Alzheimer disease. Alzheimer Dis. Assoc. Disord. 1999, 13, 216-221, DOI: 10.1097/00002093-199910000-00007

12. Holmes, S. E.; Esterlis, I.; Mazure, C. M.; Lim, Y. Y.; Ames, D.; Rainey-Smith, S.; Martins, R. N.;Salvado, O.; Dore, V.; Villemagne, V. L.; Rowe, C. C.; Laws, S. M.; Masters, C. L.; Maruff, P.; Pietrzak, R. H.Australian Imaging, B. L. R. G. beta-Amyloid, APOE and BDNF genotype, and depressive and anxiety symptoms in cognitively normal older women and men. Am. J. Geriatr Psychiatry 2016, 24, 1191-1195,DOI: 10.1016/j.jagp.2016.08.007

13. Brinton, R. D. Cellular and molecular mechanisms of estrogen regulation of memory function and neuroprotection against Alzheimer's disease: recent insights and remaining challenges. Learn. Mem. 2001,8, 121-133, DOI: 10.1101/Im.39601

14. Gartlehner, G.; Patel, S. V.; Feltner, C.; Weber, R. P.; Long, R.; Mullican, K.; Boland, E.; Lux, L.;Viswanathan, $M$. Hormone replacement therapy for the primary prevention of chronic conditions in postmenopausal women: evidence report and a systematic review of the US preventive services task force.JAMA 2017, 318, 2234- 2249, DOI: 10.1001/jama.2017.16952

15. Wang, K.; Li, F.; Chen, L.; Lai, Y. M.; Zhang, X.; Li, H. Y. Change in risk of breast cancer after receiving hormone replacement therapy by considering effect-modifiers: a systematic review and dose response meta-analysis of prospective studies. Oncotarget 2017, 8, 81109-81124, DOI: 10.18632/oncotarget.20154

16. Beral, V.; Million Women Study Collaborators Breast cancer and hormone-replacement therapy in the Million Women Study. Lancet 2003, 362, 419- 427, DOI: 10.1016/S0140-6736(03)14065-2

17. Li, C. I.; Malone, K. E.; Porter, P. L.; Weiss, N. S.; Tang, M. T.; Cushing-Haugen, K. L.; Daling, J. R.Relationship between long durations and different regimens of hormone therapy and risk of breast cancer.JAMA 2003, 289, 3254-3263, DOI: 10.1001/jama.289.24.3254

18. Anderson, G. L.; Limacher, M.; Assaf, A. R.; Bassford, T.; Beresford, S. A.; Black, H.; The Women's Health Initiative Steering CommitteeEffects of conjugated equine estrogen in postmenopausal women with hysterectomy: the Women's Health Initiative randomized controlled trial. JAMA 2004, 291, 1701-1712, DOI: 10.1001/jama.291.14.1701

19. McCullough, C.; Neumann, T. S.; Gone, J. R.; He, Z.; Herrild, C.; Wondergem (nee Lukesh), J.;Pandey, R. K.; Donaldson, W. A.; Sem, D. S. Probing the human estrogen receptor-alpha binding requirements for phenolic mono- and di-hydroxyl compounds: a combined synthesis, binding and docking study. Bioorg. Med. Chem. 2014, 22, 303-310, DOI: 10.1016/j.bmc.2013.11.024

20. Dabrota, C.; Asim, M.; Choueiri, C.; Gargaun, A.; Korobkov, I.; Butt, A.; Carlson, K. E.;Katzenellenbogen, J. A.; Wright, J. S.; Durst, T. Synthesis and receptor binding in trans-CD ring-fused A-CD estrogens: comparison with the cis-fused isomers. Bioorg. Med. Chem. Lett. 2014, 24, 3841-3844, DOI: 10.1016/j.bmcl.2014.06.066

21. Wright, J. S.; Shadnia, H.; Anderson, J. M.; Durst, T.; Asim, M.; El-Salfiti, M.; Choueiri, C.; Pratt, M. A.;Ruddy, S. C.; Lau, R.; Carlson, K. E.; Katzenellenbogen, J. A.; O’Brien, P. J.; Wan, L. A-CD estrogens. I. Substituent effects, hormone potency, and receptor subtype selectivity in a new family of flexible estrogenic compounds. J. Med. Chem. 2011, 54, 433-448, DOI: 10.1021/jm100513m

22. Asim, M.; El-Salfiti, M.; Qian, Y.; Choueiri, C.; Salari, S.; Cheng, J.; Shadnia, H.; Bal, M.;Christine Pratt, M.

A.; Carlson, K. E.; Katzenellenbogen, J. A.; Wright, J. S.; Durst, T. Deconstructing estradiol: removal of B-ring generates compounds which are potent and subtype-selective estrogen receptor agonists. Bioorg. Med. Chem. Lett. 2009, 19, 1250- 1253, DOI: 10.1016/j.bmcl.2008.12.080

23. Asim, M.; Klonowska, D.; Choueiri, C.; Korobkov, I.; Carlson, K. E.; Katzenellenbogen, J. A.; Durst, T. BC-spiroestradiols. Synthesis and estrogen receptor binding affinity of four new estradiol isomers. Bioorg. Med. Chem. Lett. 2012, 22, 3713- 3717, DOI: 10.1016/j.bmcl.2012.04.022

24. Buchanan, G. W.; Stothers, J. B.; Wu, S.-T. 13C Nuclear magnetic resonance studies. XII. Conformational effects on $13 \mathrm{C}$ shieldings in alicyclic oxygenated compounds. Can. J. Chem. 1969, 47, 3113- 3118, DOI: 10.1139/v69515

25. Patrick, D. W.; Truesdale, L. K.; Biller, S. A.; Sharpless, K. B. Stereospecific vicinal oxyamination of olefins by alkylimidoosmium compounds. J. Org. Chem. 1978, 43, 2628- 2638, DOI: 10.1021/jo00407a016

26. Brown, H. C.; Liotta, R.; Brener, L. Hydroboration. 46. The regio- and stereochemistry of the hydroboration of representative cyclic olefins with 9-borabicyclo[3.3.1]nonane. J. Am. Chem. Soc. 1977, 99, 3427-3432,DOI: 10.1021/ja00452a040 
27. Hou, X.-L.; Xie, Q.-C.; Dai, L.-X. Stereoselective metal catalysed hydroboration of 4-substituted 1methylidenecyclohexanes. J. Chem. Res., Synop. 1997, 436- 436, DOI: 10.1039/a705335e

28. CCDC 1571231 contains the supplementary crystallographic data for this paper. These data are provided free of charge by The Cambridge Crystallographic Data Centre.

29. Driscoll, J. P.; Kornecki, K.; Wolkowski, J. P.; Chupak, L.; Kalgutkar, A. S.; O’Donnell, J. P. Bioactivation of phencyclidine in rat and human liver microsomes and recombinant $\mathrm{P} 450$ 2B enzymes: evidence for the formation of a novel quinone methide intermediate. Chem. Res. Toxicol. 2007, 20, 1488-1497, DOI: $10.1021 / \mathrm{tx} 700145 \mathrm{k}$

30. Inoue, Y.; Kiryu, S.; Izawa, K.; Watanabe, M.; Tojo, A.; Ohtomo, K. Comparison of subcutaneous and intraperitoneal injection of D-luciferin for in vivo bioluminescence imaging. Eur. J. Nucl. Med. Mol. Imaging2009, 36, 771- 779, DOI: 10.1007/s00259-008-1022-8

31. Frick, K. M.; Fernandez, S. M.; Harburger, L. L. A new approach to understanding the molecular mechanisms through which estrogens affect cognition. Biochim. Biophys. Acta, Gen. Subj. 2010, 1800,1045-1055, DOI: 10.1016/j.bbagen.2009.11.004

32. Atcha, Z.; Rourke, C.; Neo, A. H.; Goh, C. W.; Lim, J. S.; Aw, C. C.; Browne, E. R.; Pemberton, D. J.Alternative method of oral dosing for rats. J. Am. Assoc. Lab. Anim. Sci. 2010, 49, 335- 343

33. Machholz, E.; Mulder, G.; Ruiz, C.; Corning, B. F.; Pritchett-Corning, K. R. Manual restraint and common compound administration routes in mice and rats. J. Visualized Exp. 2012, e2771, DOI: 10.3791/2771

34. Boulware, M. I.; Heisler, J. D.; Frick, K. M. The memory-enhancing effects of hippocampal estrogen receptor activation involve metabotropic glutamate receptor signaling. J. Neurosci. 2013, 33, 15184-15194, DOI: 10.1523/JNEUROSCI.1716-13.2013

35. Koehler, K. F.; Helguero, L. A.; Haldosen, L. A.; Warner, M.; Gustafsson, J. A. Reflections on the discovery and significance of estrogen receptor beta. Endocr. Rev. 2005, 26, 465-478, DOI: 10.1210/er.2004-0027

36. Brzozowski, A. M.; Pike, A. C.; Dauter, Z.; Hubbard, R. E.; Bonn, T.; Engström, O.; Ohman, L.;Greene, G. L.; Gustafsson, J. A.; Carlquist, M. Molecular basis of agonism and antagonism in the estrogen receptor. Nature 1997, 389, 753- 758, DOI: 10.1038/39645

37. Stierand, K.; Rarey, M. Drawing the PDB: Protein-ligand complexes in two dimensions. ACS Med. Chem. Lett. 2010, 1, 540- 545, DOI: 10.1021/ml100164p

38. Tuscher, J. J.; Fortress, A. M.; Kim, J.; Frick, K. M. Regulation of object recognition and object placement by ovarian sex steroid hormones. Behav. Brain Res. 2015, 285, 140-157, DOI: 10.1016/j.bbr.2014.08.001

39. Frye, C. A.; Duffy, C. K.; Walf, A. A. Estrogens and progestins enhance spatial learning of intact and ovariectomized rats in the object placement task. Neurobiol. Learn. Mem. 2007, 88, 208-216, DOI:

10.1016/j.nlm.2007.04.003

40. Jacome, L. F.; Gautreaux, C.; Inagaki, T.; Mohan, G.; Alves, S.; Lubbers, L. S.; Luine, V. Estradiol and ERbeta agonists enhance recognition memory, and DPN, an ERbeta agonist, alters brain monoamines. Neurobiol. Learn. Mem. 2010, 94, 488- 498, DOI: 10.1016/j.nlm.2010.08.016

41. Phan, A.; Lancaster, K. E.; Armstrong, J. N.; MacLusky, N. J.; Choleris, E. Rapid effects of estrogen receptor alpha and beta selective agonists on learning and dendritic spines in female mice. Endocrinology 2011, 152,1492-1502, DOI: 10.1210/en.2010-1273

42. Walf, A. A.; Koonce, C. J.; Frye, C. A. Estradiol or diarylpropionitrile administration to wild type, but not estrogen receptor beta knockout, mice enhances performance in the object recognition and object placement tasks. Neurobiol. Learn. Mem. 2008, 89, 513- 521, DOI: 10.1016/j.nlm.2008.01.008

43. Gillies, G. E.; McArthur, S. Estrogen actions in the brain and the basis for differential action in men and women: a case for sex-specific medicines. Pharmacol Rev. 2010, 62, 155- 198, DOI: 10.1124/pr.109.002071

44. Bodo, C.; Rissman, E. F. New roles for estrogen receptor beta in behavior and neuroendocrinology. Front. Neuroendocrinol. 2006, 27, 217-232, DOI: 10.1016/j.yfrne.2006.02.004

45. Lund, T. D.; Rovis, T.; Chung, W. C.; Handa, R. J. Novel actions of estrogen receptor-beta on anxiety-related behaviors. Endocrinology 2005, 146, 797-807, DOI: 10.1210/en.2004-1158

46. Small, S. A.; Schobel, S. A.; Buxton, R. B.; Witter, M. P.; Barnes, C. A. A pathophysiological framework of hippocampal dysfunction in ageing and disease. Nat. Rev. Neurosci. 2011, 12, 585-601, DOI: 10.1038/nrn3085

47. Piper, D. R.; Duff, S. R.; Eliason, H. C.; Frazee, W. J.; Frey, E. A.; Fuerstenau-Sharp, M.; Jachec, C.;Marks, B. D.; Pollok, B. A.; Shekhani, M. S.; Thompson, D. V.; Whitney, P.; Vogel, K. W.; Hess, S. D.Development of the 
predictor HERG fluorescence polarization assay using a membrane protein enrichment approach. Assay Drug Dev. Technol. 2008, 6, 213-223, DOI: 10.1089/adt.2008.137

48. Norman, B. H.; Richardson, T. I.; Dodge, J. A.; Pfeifer, L. A.; Durst, G. L.; Wang, Y.; Durbin, J. D.;Krishnan, V.; Dinn, S. R.; Liu, S.; Reilly, J. E.; Ryter, K. T. Benzopyrans as selective estrogen receptor beta agonists (SERBAs). Part 4: functionalization of the benzopyran A-ring. Bioorg. Med. Chem. Lett. 2007, 17,5082- 5085, DOI: 10.1016/j.bmcl.2007.07.009

49. Shiau, A. K.; Barstad, D.; Radek, J. T.; Meyers, M. J.; Nettles, K. W.; Katzenellenbogen, B. S.;Katzenellenbogen, J. A.; Agard, D. A.; Greene, G. L. Structural characterization of a subtype-selective ligand reveals a novel mode of estrogen receptor antagonism. Nat. Struct. Biol. 2002, 9, 359- 364, DOI: 10.1038/nsb787

50. Tuccinardi, T.; Bertini, S.; Martinelli, A.; Minutolo, F.; Ortore, G.; Placanica, G.; Prota, G.; Rapposelli, S.;Carlson, K. E.; Katzenellenbogen, J. A.; Macchia, M. Synthesis of anthranylaldoxime derivatives as estrogen receptor ligands and computational prediction of binding modes. J. Med. Chem. 2006, 49, 5001-5012, DOI: 10.1021/jm060560u

51. Morris, G. M.; Huey, R.; Lindstrom, W.; Sanner, M. F.; Belew, R. K.; Goodsell, D. S.; Olson, A. J. AutoDock4 and AutoDockTools4: Automated docking with selective receptor flexibility. J. Comput. Chem. 2009, 30,2785-2791, DOI: 10.1002/jcc.21256

52. Cavasotto, C. N.; Orry, A. J. W. Ligand docking and structure-based virtual screening in drug discovery.Curr. Top. Med. Chem. 2007, 7, 1006-1014, DOI: 10.2174/156802607780906753

53. Goodsell, D. S.; Morris, G. M.; Olson, A. J. Automated docking of flexible ligands: applications of AutoDock.J. Mol. Recognit. 1996, 9, 1- 5, DOI: 10.1002/(SICI)1099-1352(199601)9:1<1::AID-JMR241>3.0.CO;2-6

54. Huey, R.; Morris, G. M.; Olson, A. J.; Goodsell, D. S. A semiempirical free energy force field with charge-based desolvation. J. Comput. Chem. 2007, 28, 1145-1152, DOI: 10.1002/jcc.20634

55. Morris, G. M.; Goodsell, D. S.; Halliday, R. S.; Huey, R.; Hart, W. E.; Belew, R. K.; Olson, A. J. Automated docking using a Lamarckian genetic algorithm and an empirical binding free energy function. J. Comput. Chem. 1998, 19, 1639- 1662, DOI: 10.1002/(SICI)1096-987X(19981115)19:14<1639::AID-JCC10>3.0.CO;2-B

56. Li, Z.; Zhang, H.; Gibson, M.; Li, J. An evaluation on combination effects of phenolic endocrine disruptors by estrogen receptor binding assay. Toxicol. In Vitro 2012, 26, 769- 774, DOI: 10.1016/j.tiv.2012.05.017

57. Fortress, A. M.; Fan, L.; Orr, P. T.; Zhao, Z.; Frick, K. M. Estradiol-induced object recognition memory consolidation is dependent on activation of mTOR signaling in the dorsal hippocampus. Learn. Mem. 2013,20, 147-155, DOI: 10.1101/lm.026732.112

58. Kim, J.; Szinte, J. S.; Boulware, M. I.; Frick, K. M. 17 beta-estradiol and agonism of G-protein-coupled estrogen receptor enhance hippocampal memory via different cell-signaling mechanisms. J. Neurosci. 2016,36, 3309- 3321, DOI: 10.1523/JNEUROSCI.0257-15.2016

59. Meyers, M. J.; Sun, J.; Carlson, K. E.; Marriner, G. A.; Katzenellenbogen, B. S.; Katzenellenbogen, J. A.Estrogen receptor-beta potency-selective ligands: structure-activity relationship studies of diarylpropionitriles and their acetylene and polar analogues. J. Med. Chem. 2001, 44, 4230-4251, DOI: 10.1021/jm010254a

60. Baker, K. B.; Kim, J. J. Effects of stress and hippocampal NMDA receptor antagonism on recognition memory in rats. Learn. Mem. 2002, 9, 58- 65, DOI: 10.1101/lm.46102

61. Luine, V. N.; Jacome, L. F.; Maclusky, N. J. Rapid enhancement of visual and place memory by estrogens in rats. Endocrinology 2003, 144, 2836- 2844, DOI: 10.1210/en.2003-0004

62. Cohen, S. J.; Munchow, A. H.; Rios, L. M.; Zhang, G.; Asgeirsdottir, H. N.; Stackman, R. W., Jr. The rodent hippocampus is essential for nonspatial object memory. Curr. Biol. 2013, 23, 1685-1690, DOI: 10.1016/j.cub.2013.07.002 